\title{
Akt inhibitors in cancer treatment: The long journey from drug discovery to clinical use (Review)
}

\author{
GEORGE MIHAI NITULESCU ${ }^{1}$, DENISA MARGINA ${ }^{1}$, PETRAS JUZENAS $^{2}$, QIAN PENG $^{2}$, \\ OCTAVIAN TUDOREL OLARU ${ }^{1}$, EMMANOUIL SALOUSTROS ${ }^{3}$, CONCETTINA FENGA $^{4}$, \\ DEMETRIOS A. SPANDIDOS ${ }^{5}$, MASSIMO LIBRA $^{6}$ and ARISTIDIS M. TSATSAKIS ${ }^{7}$
}

\author{
${ }^{1}$ Faculty of Pharmacy, 'Carol Davila' University of Medicine and Pharmacy, Bucharest 020956, Romania; \\ ${ }^{2}$ Department of Pathology, Radiumhospitalet, Oslo University Hospital, 0379 Oslo, Norway; ${ }^{3}$ Oncology Unit, \\ General Hospital of Heraklion 'Venizelio', Heraklion 71409, Greece; ${ }^{4}$ Section of Occupational Medicine, \\ University of Messina, I-98125 Messina, Italy; ${ }^{5}$ Department of Virology, Faculty of Medicine, University of Crete, \\ Heraklion 71003, Greece; ${ }^{6}$ Department of Biomedical and Biotechnological Sciences, General and Clinical Pathology \\ and Oncology Section, University of Catania, I-95124 Catania, Italy; ${ }^{7}$ Department of Forensic Sciences \\ and Toxicology, Faculty of Medicine, University of Crete, Heraklion 71003, Greece
}

Received November 17, 2015; Accepted December 24, 2015

DOI: 10.3892/ijo.2015.3306

\begin{abstract}
Targeted cancer therapies are used to inhibit the growth, progression, and metastasis of the tumor by interfering with specific molecular targets and are currently the focus of anticancer drug development. Protein kinase B, also known as Akt, plays a central role in many types of cancer and has been validated as a therapeutic target nearly two decades ago. This review summarizes the intracellular functions of Akt as a pivotal point of converging signaling pathways involved in cell growth, proliferation, apoptotis and neo-angiogenesis, and focuses on the drug design strategies to develop potent anticancer agents targeting Akt. The discovery process of Akt inhibitors has evolved from adenosine triphosphate (ATP)-competitive agents to alternative approaches employing allosteric sites in order to overcome the high degree of structural similarity between Akt isoforms in the catalytic domain, and considerable structural analogy to the AGC kinase family. This process has led to the discovery of inhibitors with greater specificity, reduced side-effects and lower toxicity. A second generation of Akt has inhibitors emerged by incorporating a chemically reactive Michael acceptor template to target the nucleophile cysteines in the catalytic activation loop. The review outlines the development of several promising drug candidates emphasizing the
\end{abstract}

Correspondence to: Dr Denisa Margina, Faculty of Pharmacy, 'Carol Davila' University of Medicine and Pharmacy, 6 Traian Vuia Street, Bucharest 020956, Romania

E-mail: denisa.margina@gmail.com

Key words: phosphatase and tensin homolog, PH domain, ATPcompetitive inhibitors, AZD5363, ipatasertib, uprosertib, afuresertib, MK-2206, perifosine, triciribine importance of each chemical scaffold. We explore the pipeline of Akt inhibitors and their preclinical and clinical examination status, presenting the potential clinical application of these agents as a monotherapy or in combination with ionizing radiation, other targeted therapies, or chemotherapy.
Contents
1. Introduction
2. Akt structure and function
3. Akt inhibitors as anticancer agents
4. ATP-competitive inhibitors
5. Allosteric inhibitors
6. Irreversible inhibitors
7. Clinically relevant Akt inhibitors
8. Potential biomarker for Akt inhibitors
9. Conclusions

\section{Introduction}

Cancer is defined by the American Cancer Society as a group of diseases characterized by the uncontrolled growth and spread of abnormal cells. The World Health Organization (WHO) states that one defining feature of cancer is the rapid creation of abnormal cells that grow beyond their usual boundaries, and which can then invade adjoining parts of the body and spread to other organs. This growth is caused by either external factors (tobacco, infectious organisms and an unhealthy diet), or by internal factors (inherited genetic mutations, hormones, and immune conditions) (www.cancer.org).

Cancer can have severe health consequences, and is a leading cause of mortality worlwide; there are 8.2 million cancer-related deaths, which corresponds to $13 \%$ of all deaths worldwide. Data from the Cancer Research UK indicated that 
in 2012, approximately 14.1 million new cases of cancer were diagnosed in worldwide. Among these cases, 7.4 million (53\%) were diagnosed in males and 6.7 million (47\%) in females, with a male-to-female ratio of 10:9. The world age-standardized incidence rate points out that there are 205 new cancer cases for every 100,000 males worldwide, and 165 for every 100,000 females (1).

According to WHO, lung, prostate, colorectal, stomach and liver cancer are the most common types of cancer in males, while breast, colorectal, lung, uterine cervix and stomach cancer are the most common among females. Statistics also indicate that there is expected to be a $70 \%$ increase in new cancer cases over the next two decades. The American Cancer Society released the analysis for 2015 , projecting that there will be an estimated 1,658,370 new cancer cases diagnosed and 589,430 cancer-related deaths in the US (2).

Presently, there are over 100 types of cancer, which require a great effort for diagnosis and treatment; due to this high incidence and high risk for public health, intense research designed into this topic is being carried out worldwide.

Over the past decades, a growing body of evidence has indicated that cancer patients can be cured by novel molecular target therapies due to the molecular characterization of the tumor from each patient. The phosphatidylinositol 3-kinase (PI3K)/Akt pathway is aberrantly activated in several types of cancers and targeting this pathway with drug inhibitors may result in more effective anticancer treatment for both solid and hematologic tumors (3). In this review, recent data regarding the regulation of the PI3K/Akt signal transduction pathway and its involvement in the development and progression cancer are discussed. Furthermore, the most relevant studies focusing on the specific action of new molecular targeted agents are discussed.

\section{Akt structure and function}

The serine/threonine kinase Akt, also known as protein kinase B or PKB, with three isoforms (Akt1, Akt2 and Akt3), plays a critical role in regulating diverse cellular functions (Fig. 1) including cell size/growth, proliferation, survival, glucose metabolism, genome stability, transcription and protein synthesis, and neovascularization (4). One of the major functions of $\mathrm{Akt} / \mathrm{PKB}$ is to promote growth factor-mediated cell survival, to promote cell proliferation and to inhibit apoptosis through the inactivation of pro-apoptotic proteins, such as Bad (Bcl-2 antagonist of cell death) and mouse double minute 2 homolog (MDM2; which causes the degradation of p53) (5).

Studies have proven that the Akt signaling cascade is frequently impaired in many types of cancer and, in some cases, that it is associated with tumor aggressiveness. These are the reasons for considering this signaling pathway as a strong target candidate for cancer therapy or even cancer prevention $(6,7)$.

The Akt structure consists of a three domains: i) an amino terminal pleckstrin homology $(\mathrm{PH})$ domain, consisting of 100 amino acids, sharing similarity to those found in other signaling molecules binding 3-phosphoinositide; this domain interacts with membrane lipid products, such as phosphatidylinositol-3,4,5-triphosphate (PIP3) and phosphatidylinositol 4,5-bisphosphate (PIP2); ii) a central kinase domain, highly similar to other cAMP-dependent protein kinase $\mathrm{C}$ (AGC kinases), containing a regulatory threonine residue (Thr308) which phosphorylation activates Akt; iii) a carboxyl-terminal regulatory domain containing the hydrophobic region consisting of 40 amino acids, including the serine regulatory residue (Ser473) (8).

Akt isoforms share a high degree of sequence homology in their catalytic domains, but diverge in the regulatory domain and the PH domain. Akt1 and Akt2 are ubiquitously expressed, whereas Akt 3 is found predominantly in the brain, heart and kidneys (9). The catalytic domain of Akt displays a high degree of similarity to those found in cAMP-dependent protein kinase or protein kinase $\mathrm{A}$ (PKA) and protein kinase $\mathrm{C}$ (PKC), hence the other name of Akt, protein kinase B (PKB). Structurally, and functionally, Akt belongs to the AGC kinase family, a group named after its major representatives, the PKA, the cGMP-dependent protein kinase or protein kinase $\mathrm{G}$ (PKG) and PKC (10).

Akt, together with PI3K, are the key elements of the Akt signaling cascade, also known as PI3K/Akt, a signal transduction pathway that promotes survival and growth in response to extracellular signals (5). This signaling cascade can be activated by receptor tyrosine kinases, integrins, $\mathrm{B}$ and $\mathrm{T}$ cell receptors, cytokine receptors, G-protein-coupled receptors and other stimuli that induce production of PIP3 $(11,12)$. PI3K is overexpressed in ovarian and cervical cancer and has mutations associated with breast cancer, glioblastoma and gastric cancer $(13,14)$.

The activation of Akt firstly involves a PH domain-dependent membrane translocation step, followed by the phosphorylation of the two key regulatory sites, Thr308 and Ser473 (15). Various signaling events activate PI3K to phosphorilate its membrane substrate, PIP2, generating PIP3 (16). PIP3 recruits Akt to the plasma membrane by interacting with the $\mathrm{PH}$ domain and modifies its conformation to allow subsequent phosphorylation by the phosphoinositide-dependent kinase-1 (PDK1) at the Thr308 site in the regulatory domain (17). This signaling event primes Akt for phosphorylation at Ser473 by mechanistic target of rapamycin (mTOR)C2 (16). Members of the PI3K-related kinase family, including DNA-PK, can also phosphorylate Akt at Ser473 (18). In addition, there are some binding proteins which regulate the activity of Akt [actin, extracellular signalregulated protein kinase (Erk)1/2, heat shock protein (Hsp)90, Hsp27 and Posh]. For example, Hsp90 uses repeated cycles of client protein binding, the hydrolysis of adenosine triphosphate (ATP) and interaction with its co-chaperones, such as Hsp70, Cdc37, HOP, p23 and activator of heat shock $90 \mathrm{kDa}$ protein ATPase homolog 1 (Aha1) to control the stability and activity of hundreds of client proteins involved in critical signaling pathways necessary for cellular proliferation, cell cycle progression, and apoptosis, including Akt (19).

Akt is dephosphorylated by protein phosphatase 2A (PP2A) and the $\mathrm{PH}$ domain leucine-rich-repeat-containing protein phosphatase 1/2 (PHLPP2). In addition, the tumor suppressor, phosphatase and tensin homolog (PTEN), inhibits Akt activity by dephosphorylating PIP3 (20).

Activated Akt modulates the function of numerous substrates involved in the regulation of cell survival, cell cycle progression and cellular growth (21). Akt modulates cellular processes by phosphorylating different substrates, such as proline-rich Akt substrate of $40 \mathrm{kDa}$ (PRAS40), actin-associated protein paladin, CDK inhibitors p21 and p27, palladin and vimentin, IKK $\alpha$ and Tpl2 (9). Akt regulates cell 


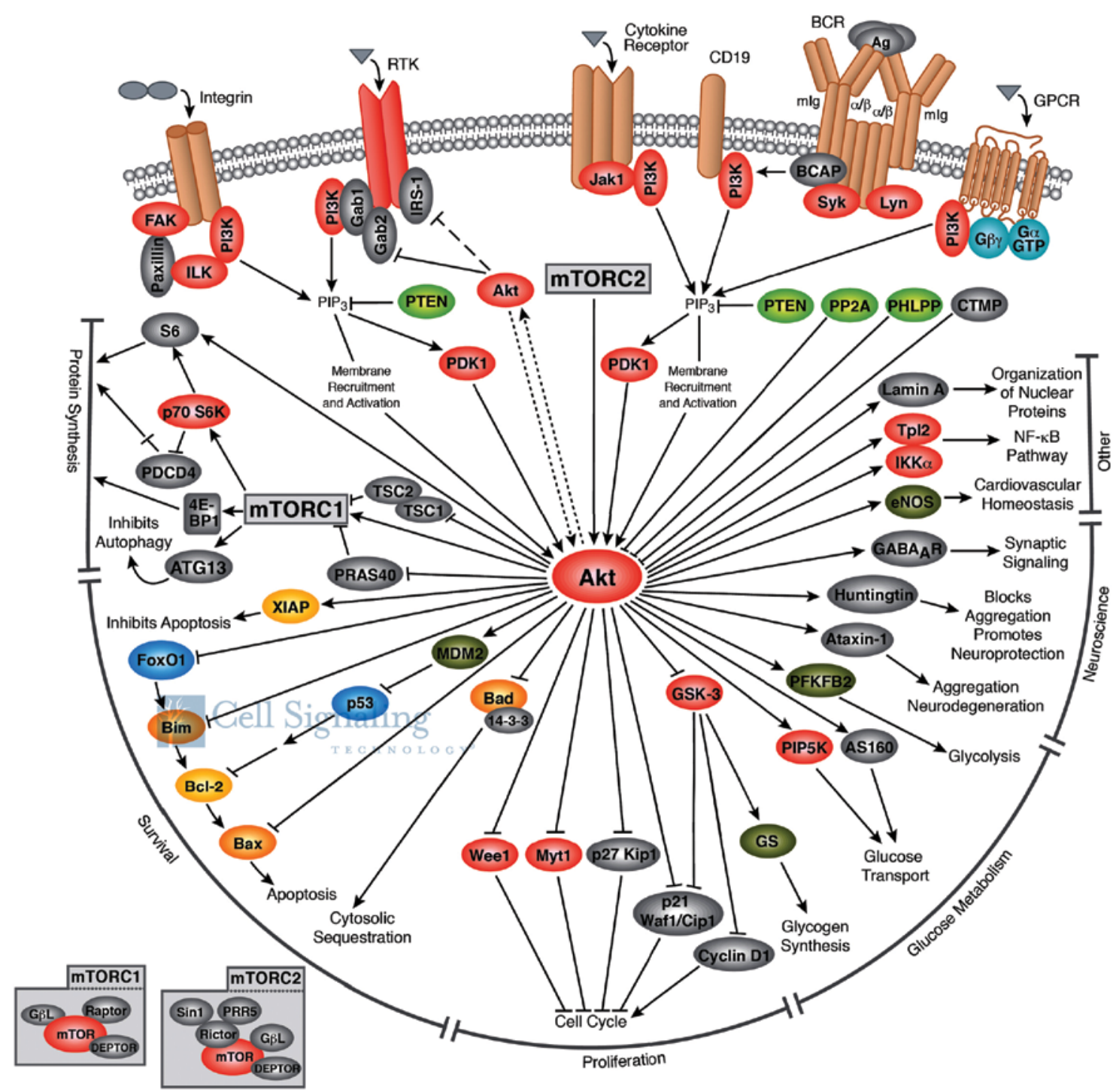

Figure 1. Schematic representation of the Akt pathway and downstream effectors. Illustration reproduced courtesy of Cell Signaling Technology, Inc., Beverly, MA, USA (www.cellsignal.com).

growth (Fig. 1) through its effects on the TSC1/TSC2 complex and mTORC signaling and acts as a major mediator of cell survival through the direct inhibition of pro-apoptotic proteins, such as Bad or through the inhibition of pro-apoptotic signals generated by transcription factors, such as Forkhead box protein $\mathrm{O} 1$ (FoxO) (22).

mTOR is a downstream member of the PI3K/Akt and adenosine monophosphate-activated protein kinase pathways, and is a key regulator of cell growth and metabolism. mTOR (Fig. 1) is a component of two similar complexes: mTORC1, which promotes mRNA translation and protein synthesis by the phosphorylation of ribosomal protein S6 kinase (S6K1) and eIF4E binding protein 1 (4E-BP1) and mTORC2, which organizes the cellular actin cytoskeleton and regulates Akt phosphorylation (22).

As Akt isoforms share a high degree of structural similarity, it has long been assumed that their functions largely overlap. However, Akt1 has a cardio-protective role by supporting heart's physiological growth and function (23). Strong evidence indicates a significant association between schizophrenia and a decrease in Akt1 levels (24). As previously demonstrated, hyperglycemia and reduced glucose transport in muscle are present in knockout Akt2 mice, but not following the depletion of Akt1 or Akt3 (25). A recent study indicated that both Akt1 and Akt2 contribute to insulin-dependent glucose transporter type 4 (GLUT4) translocation to the membrane (26). Akt3 does not appear to significantly influence normal metabolism, but it is critical for brain development; several Akt3 mutations have been reported in neurological disorders (27).

\section{Akt inhibitors as anticancer agents}

The Akt pathway is one of the most frequently deregulated signaling pathways in human cancers with many of its components described as altered. The activation of the Akt pathway plays an essential role in cell survival, proliferation, migration and differentiation, contributing to tumorigenesis and tumor metastasis. The overexpression and activation of Akt are often associated with resistance to chemotherapy or radiotherapy (28). Our preliminary results, which are still unpublished, suggest that 
Table I. Akt-inhibiting drugs listed into major classes.

Class

Description

$\begin{array}{ll}\text { ATP-competitive inhibitors } & \text { Orthosteric inhibitors targeting the ATP-binding pocket of the protein kinase B (Akt) } \\ \text { Isoquinoline-5-sulfonamides } & \text { H-8, H-89, NL-71-101 } \\ \text { Azepane derivatives } & \text { A series structures derived from (-)-balanol } \\ \text { Aminofurazans } & \text { GSK690693 } \\ \text { Heterocyclic rings } & \text { 7-azaindole, 6-phenylpurine derivatives, pyrrolo[2,3-d]pyrimidine derivatives, CCT128930, } \\ & \text { 3-aminopyrrolidine, anilinotriazole derivatives, spiroindoline derivatives, } \\ & \text { AZD5363, ipatasertib (GDC-0068, RG7440), A-674563, A-443654 } \\ \text { Phenylpyrazole derivatives } & \text { AT7867, AT13148 } \\ \text { Thiophenecarboxamide } & \text { Afuresertib (GSK2110183), 2-pyrimidyl-5-amidothiophene derivative (DC120), uprosertib } \\ \text { derivatives } & \text { (GSK2141795) }\end{array}$

Allosteric inhibitors

Superior to orthosteric inhibitors providing greater specificity, reduced side-effects and less toxicity

2,3-diphenylquinoxaline analogues

2,3-diphenylquinoxaline derivatives, triazolo[3,4-f][1,6]naphthyridin-3(2H)-one derivative (MK-2206)

Alkylphospholipids

Edelfosine (1-O-octadecyl-2-O-methyl-rac-glycero-3-phosphocholine, ET-18-OCH $)$ ilmofosine (BM 41.440), miltefosine (hexadecylphosphocholine, HePC), perifosine (D-21266), erucylphosphocholine (ErPC), erufosine (ErPC3, erucylphosphohomocholine

Indole-3-carbinol analogues Indole-3-carbinol,3-chloroacetylindole, diindolylmethane, diethyl 6-methoxy-5,7-dihydroindolo [2,3-b]carbazole-2,10-dicarboxylate (SR13668), OSU-A9

Sulfonamide derivatives PH-316, PHT-427

Thiourea derivatives

Purine derivatives

PIT-1, PIT-2, DM-PIT-1, N-[(1-methyl-1H-pyrazol-4-yl)carbonyl]-N'-(3-bromophenyl)-thiourea Triciribine (TCN, NSC 154020), triciribine mono-phosphate active analogue (TCN-P), 4-amino-pyrido[2,3- $d$ ]pyrimidine derivative API-1, 3-phenyl-3H-imidazo[4,5- $b]$ pyridine derivatives, ARQ 092

Other structures, derivatives BAY 1125976,3-methyl-xanthine, quinoline-4-carboxamide and 2-[4-(cyclohexa-1,3-dien-1-yl)$1 H$-pyrazol-3-yl]phenol, 3-oxo-tirucallic acid, $3 \alpha$ - and $3 \beta$ - acetoxy-tirucallic acids, acetoxy-tirucallic acid

Irreversible inhibitors

Natural products, antibiotics

Lactoquinomycin, Frenolicin B, kalafungin, medermycin, Boc-Phe-vinyl ketone,

4-hydroxynonenal (4-HNE), 1,6-naphthyridinone derivatives, imidazo-1,2-pyridine derivatives

Akt activation is observed in melanoma samples from patients with occupational sun exposure. Such an Akt activation has also been identified in melanoma samples, previously screened for B-RAF ${ }^{\mathrm{V} 600 \mathrm{E}}$ mutations (29), harboring both B-RAF ${ }^{\mathrm{V} 600 \mathrm{E}}$ and $\mathrm{PI} 3 \mathrm{~K}^{\mathrm{H} 1047 \mathrm{R}}$. Intriguingly, both mutations were detected among indoor workers with intermittent sun exposure, suggesting that Akt activation may be linked with a previous damage to DNA by ultraviolet (UV) light.

Akt is also overexpressed or activated in a variety of human cancers, including lung, breast, ovarian, gastric and pancreatic carcinomas (30). PTEN activity can be impaired by mutations, deletions or promoter methylation in many primary and metastatic human cancers, and activating mutations of PI3K have been observed in various human tumors (31). It has been demonstrated that a low PTEN expression correlates with poor responses to trastuzumab-based therapy (33) and it has been hypothesized that Akt inhibitors may be useful in these cases. Various substances that can also increase PTEN levels are under investigation as anticancer therapies, such as the proteasome inhibitor, bortezomib (34), and the natural lignans, deoxypodophyllotoxin (35) and matairesinol (36).
An oncogenetic activating mutation (E17K) in the $\mathrm{PH}$ domain of Akt1 has been detected in some types of solid tumors. This mutation has been reported in breast $(5.9 \%)$, colorectal $(1.6 \%)$, lung $(0.6 \%)$ and ovarian cancers $(0.8 \%)$, as well as in melanoma $(0.5 \%)(37)$. Akt1 is frequently elevated in breast and prostate cancers. The amplification and overexpression of Akt2 has been shown to correlate with the aggressiveness of cancer and poor survival rates, and is frequently detected in prostate, ovarian, breast, pancreatic and colorectal cancers (38-40). In previous studies, the immunohistochemical staining of clinical samples revealed that Akt3 protein expression was upregulated in androgen-independent prostate cancer cell lines, estrogen receptor-deficient breast cancer cells (41) and in primary ovarian cancers (42).

Akt is considered as an attractive target for cancer therapy and multiple attempts to identify specific inhibitors with acceptable pharmaceutical properties have been pursued. Despite significant progress being made, selectivity is a key issue for many ATP-competitive Akt inhibitors, particularly towards the AGC kinase family. The development of Akt inhibitors has been also hampered by the existence of three isozymes, 
<smiles>CNCCNS(=O)(=O)c1cccc2cnccc12</smiles><smiles>O=S(=O)(NCCNC/C=C/c1ccc(Br)cc1)c1cccc2cnccc12</smiles><smiles>N#[W][W]=[W]=NCCNCCNS(=O)(=O)c1cccc2cnccc12</smiles>

Figure 2. Structures of H-8, H-89 and NL-71-101.

which differ in function, tissue distribution and affinity for ligands (43). The development of Akt-specific and isoformselective inhibitors using the catalytic domain of the kinase has been predicted to be difficult due to high sequence homology, determining alternative and novel approaches to target Akt and to identify allosteric inhibitors (44).

The major Akt inhibitors classified by the inhibition mechanisms and by their chemical scaffold are presented in Table I.

\section{ATP-competitive inhibitors}

Isoquinoline-5-sulfonamides. One of the first relatively selective inhibitors of Akt was NL-71-101, obtained after the screening of a combinatorial library designed using the structure of the isoquinoline-5-sulfonamide derivative, H-89, as a starting point (Fig. 2). H-89 is a potent inhibitor of PKA and it was observed to inhibit the growth of the human colon cancer cell line, Caco-2, in a dose-dependent manner, while the congener derivative, $\mathrm{H}-8$, did not. $\mathrm{H}-89$ proved to be an inhibitor of Akt and opened a new direction for development of Akt inhibitors (45). H-89 has been shown to inhibit PKA 70 -fold more potently than Akt, but NL-71-101 is relatively selective towards Akt, inhibiting it 2-3-fold more potently than PKA (46). This compound induces the apoptosis of ovarian carcinoma cells at high concentrations (43).

Azepane derivatives. A similar strategy was used to improve the inhibition of Akt over PKA, starting from the natural fungal metabolite, (-)-balanol. The ester moiety of the balanol is responsible for its low stability and was replaced with an amide group rendering a new series of azepane inhibitors of Akt (47). Most programs to develop ATP-competitive inhibitors of Akt are driven by achieving selectivity towards PKA because of its role over key cell functions (48).

Aminofurazans. GSK690693 is an aminofurazan derivative, ATP-competitive inhibitor with $\mathrm{IC}_{50}$ values of 2,13 and $9 \mathrm{nM}$ against Akt 1, 2 and 3, respectively (49). In preclinical studies, GSK690693 was shown to inhibit the proliferation of various hematologic neoplasia, with acute lymphoblastic leukemia cell lines being the most sensitive (50), but exerted limited effects on xenograft models (51). The clinical development of this compound was terminated due to the associated side-effect of transient hyperglycemia (52).
Compounds with heterocyclic 6-5 fused rings. Virtual, biochemical and crystallographic screens identified 7-azaindole as an important small fragment for the design of Akt inhibitors. The optimization of the scaffold advanced to the development of 6-phenylpurine (53) and afterwards to pyrrolo[2,3- $d]$ pyrimidine derivatives. The coupling of the 4-aminopiperidine and pyrrolopyrimidine moieties afforded CCT128930 and provided selectivity over PKA (54). CCT128930 (Fig. 3) has been shown to inhibit the phosphorylation of a range of Akt substrates and to induce marked antitumor responses in various cancer cell lines (55). The pyrrolopyrimidine scaffold was used extensively in the development of various Akt inhibitors. The replacement of the piperidine ring in the structure of CCT128930 has led to a series of 3-aminopyrrolidines with a very good selectivity over PKA (56). A high throughput in vitro kinase assay of pyrrolopyrimidines has led to the development of a potent Akt1 inhibitor with an anilinotriazole structure. Further development replaced the anilinotriazole moiety with an imidazopiperidine which led to the discovery of the spiroindolines scaffold as linker to the pyrrolo[2,3- $d$ ] pyrimidine (57).

In order to improve the rapid in vivo metabolism and low oral bioavailability of CCT128930, the 4-amino-4-benzylpiperidine moiety was modified to 4-amino-piperidine-4-carboxamide, leading to the development of AZD5363 (58).

AZD5363 (Fig. 3) has been shown to inhibit all Akt isoforms with a potency of $\leq 10 \mathrm{nmol} / \mathrm{l}$ and has shown reduced $\mathrm{hERG}$ affinity, and a higher selectivity against the closely related Rho-associated protein kinase (ROCK) in addition to good pharmacokinetics properties (59). Treatment with AZD5363 has been shown to inhibit the proliferation of 41 of 182 solid and hematological tumor cell lines with a potency of $\leq 3 \mu \mathrm{mol} / 1$ and the highest frequency of sensitivity was observed in breast cancer cells. AZD5363 significantly enhanced the antitumor activity of docetaxel, lapatinib and trastuzumab in breast cancer xenografts. The activity of AZD5363 in human epidermal growth factor receptor 2 (HER2)-amplified breast cancer cells was enhanced by the addition of a pan-erbB [epidermal growth factor receptor (EGFR)] tyrosine kinase (60). Several clinical assays of phase I and II are undergoing to assess the AZD5363 in breast, gastric and prostate cancers (61).

Ipatasertib (GDC-0068, RG7440) was the result of the discovery and optimization of a series of 6,7-dihydro- $5 \mathrm{H}$ cyclopenta[d]pyrimidine compounds. It is orally bioavailable and has demonstrated potent inhibition of all three Akt isoforms 
<smiles>NC1(Cc2ccc(Cl)cc2)CCN(c2ncnc3[nH]ccc23)CC1</smiles>

CCT128930<smiles>NC1(C(=O)N[C@@H](CCO)c2ccc(Cl)cc2)CCN(c2ncnc3[nH]ccc23)CC1</smiles>

AZD5363<smiles>CC(C)NC[C@H](C(=O)N1CCN(c2ncnc3c2[C@@H](C)CC3O)CC1)c1ccc(Cl)cc1</smiles><smiles>Cc1[nH]nc2ccc(-c3cncc(OCC(N)Cc4ccccc4)c3)cc12</smiles>

A-674563<smiles>Cc1[nH]nc2ccc(-c3cncc(OC[C@H](N)Cc4c[nH]c5ccccc45)c3)cc12</smiles>

Figure 3. Pyrrolo[2,3-d]pyrimidine, cyclopenta[d]pyrimidine and indazole derivatives as Akt inhibitors.

and a poor inhibition of other members of the PKA family (62). Treatmetn with ipatasertib has been shown to inhibit Akt signaling in both human cancer cell lines and in tumor xenograft models, resulting in the blockade of cell cycle progression the decreased viability of cancer cell lines (63). Ipatasertib is currently under evaluation in several clinical phase I and II trials (NCT02430363 and NCT02301988). In a phase Ib clinical study, the combination of ipatasertib with paclitaxel was well-tolerated and a phase II study designed to estimate the efficacy of this combination in metastatic triple-negative breast cancer patients is in progress (64).

A-674563 and A-443654 (Fig. 3) were the result of a high-throughput screening hit which weakly inhibited Akt. The potency was improved by the addition of an indole ring to the aliphatic side chain and by constraining rotatable bonds between the central and distal pyridine rings by forming an isoquinoline ring. The isoquinoline moiety was transformed in an indazole ring to afford a second hydrogen interaction to the hinge region, resulting in A-443654. The replacement the indole with a phenyl moiety resulted in compound A-674563 and provided oral bioavailability (65). These compounds are potent, ATP-competitive and reversible inhibitors of Akt. A-443654 has equal potency against Akt isoforms and is 40-fold more selective for Akt over PKA, while A-674563 is less selective, particularly against the cyclin-dependent kinases (66). Both compounds behave similarly in vivo antitumor activity assay, with A-443654 being more potent and more selective than A-674563. The both derivatives increased the efficacy of paclitaxel in a prostate carcinoma cell xenograft model (65).

Several other nitrogen compounds containing 6-5 fused rings have proven to be good templates for the development of potent Akt inhibitors. Azaindazole and 4,7-diazaindazole were incorporated in the structure of tetrasubstituted aminopyridines providing potent and selective Akt inhibitors (67).
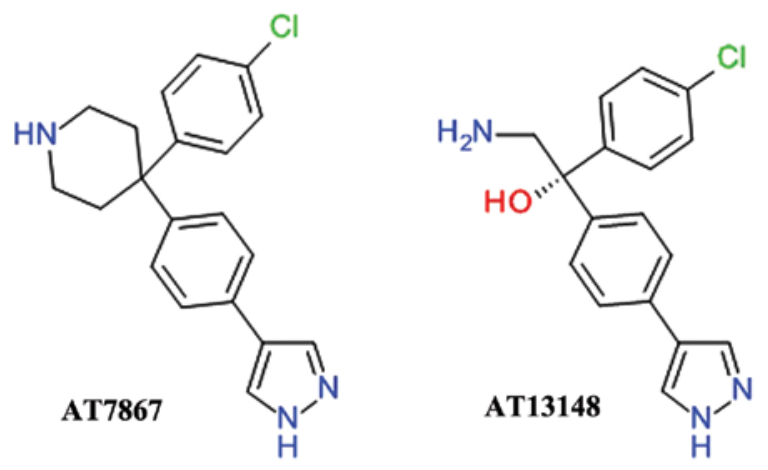

Figure 4. Structures of AT7867 and AT13148.

A series of $1 H$-indazole-4,7-diones have been shown to exert dual inhibitory effects on both the activity and phosphorylation of Akt1 in the PC-3 tumor cell line (68). Dihydrothieno- and dihydrofuro- pyrimidine scaffolds generated potent pan Akt inhibitors (69). GSK690693, described above and classified as an aminofurazane derivative, can also be included in the 6-5 fused rings group based on its imidazo[4,5-c]pyridine core.

Phenylpyrazole derivatives. AT7867 was developed using fragment- and structure-based drug design starting from the discovery of 4-phenylpyrazole as week Akt inhibitor. The inhibition of Akt 2 by AT7867 was shown to be ATP-competitive and the binding at the ATP site was confirmed by determining the three-dimensional structure of the ligand-enzyme complex using X-ray crystallography (70). AT7867 (Fig. 4) is an oral potent inhibitor of all Akt isoforms and of the downstream p70 S6 kinase (p70 S6K) and also of PKA. It suppresses cell proliferation, and induces the apoptosis of a range of human cancer cell lines, but is still in preclinical studies (71). 


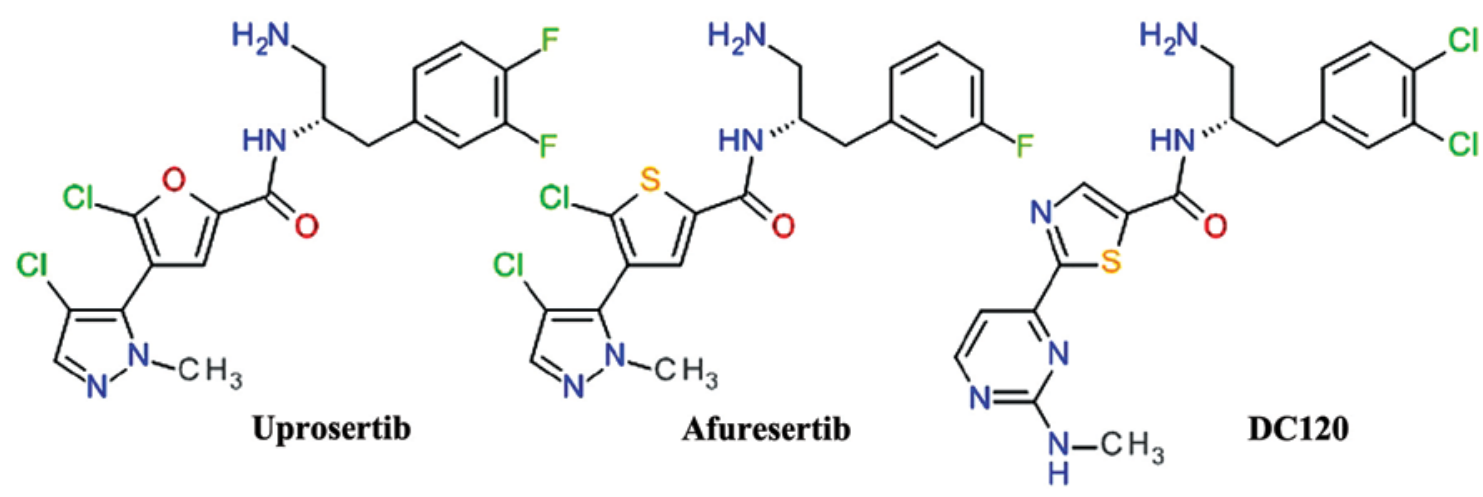

Figure 5. Derivatives of thiophene and related five membered rings.

AT13148 (Fig. 4) was identified using high-throughput X-ray crystallography and fragment-based lead discovery techniques starting from a 4-phenylpyrazole scaffold, such as AT7867. Both compounds share a high degree of structural similarity and, accordingly, comparable inhibitions profiles. AT13148 is an ATP-competitive multi-AGC kinase inhibitor blocking Akt, p70 S6K, PKA, ROCK, and serum and glucocorticoid-inducible kinase (SGK). It has a marked apoptotic rather than cytostatic profile, emphasizing the functional differences between its properties as a multi-kinase inhibitor in contrast with the selective Akt inhibitors (72).

Thiophenecarboxamides and derivatives. A derivate of 2-pyrimidyl-5-amidothiophene was identified as an ATP-competitive inhibitor of Akt3 using high throughput screening. The lead optimization based on structure-activity associations demonstrated the importance of the amide bond and the optimal length of two carbon atoms between the phenyl ring and the amide nitrogen (73). The replacement of the pyrimidine moiety proved to be useful, especially with a pyrazole ring, resulting in the development of afuresertib (GSK2110183) (74). In the series of 2-pyrimidyl-5-amidothiophene derivatives, the transformation of the thiophene in thiazole afforded a new lead compound DC120 (75). For both related compounds, afuresertib and DC120 (Fig. 5), the stereochemistry of the isomers is very important for the enzyme inhibition.

DC120 has been shown to inhibit the proliferation of CNE2 and MDA-MB-453 cells via the induction of apoptosis mediated by cleaved caspase- 3 and reduced the phosphorylation levels of forkhead transcription factor (FKHR), glycogen synthase kinase $3 \beta$ (GSK-3 $\beta$ ) and mTOR in a dose- and time-dependent manner. In xenograft models, DC120 inhibited CNE2 tumor growth (76).

Afuresertib (GSK2110183) is a highly potent inhibitor of Akt, with subnanomolar potency against Akt1 and low nanomolar potency against Akt2 and Akt3. Proliferation assays of human tumor cell lines demonstrated that the hematological cell lines were the most sensitive, mostly acute lymphoblastic leukemia, non-Hodgkin's lymphoma and chronic lymphocytic leukemia (74). In a clinical study, afuresertib (PKB112835) was shown to be safe and well-tolerated. It produced a relatively low incidence and magnitude of hyperglycemia, due to the improved kinase selectivity versus other PKC isoforms.
Afuresertib proved its clinical efficacy in a number of hematological malignancies, particularly in multiple myeloma (77). A phase I/II study on afuresertib in combination with bortezomib and dexamethasone in patients with relapsed or refractory myeloma showed an overall response rate of $41 \%$ (78).

Uprosertib (GSK2141795) is a structurally close analog of afuresertib, the main difference being the replacement of the thiophene core with its bioisostere furan ring (Fig. 5). The inhibition of Akt and anti-proliferative effect of uprosertib is similar to that of afuresertib, with uprosertib being more potent and having greater off-target kinase inhibition. It is was tested clinically alone or in combination with trametinib (MEK inhibitor) in various types of cancer (74).

\section{Allosteric inhibitors}

ATP-competitive inhibitors are non-selective against Akt isozymes, and poorly selective against closely related kinases, as the catalytic domain is highly similar. Efforts to identify Akt-specific and isoform-selective inhibitors have resulted in the discovery of allosteric inhibitors (79). Allosteric modulators offer distinct advantages compared to orthosteric ligands that target to active sites, such as greater specificity, reduced side-effects and lower toxicity (80).

2,3-Diphenylquinoxaline and analogs. One of the first allosteric inhibitors of Akt was a 2,3-diphenylquinoxaline derivative that demonstrated potent inhibitory effects against Akt1, but no effect on the mutated Akt enzyme depleted of the PH domain (81). The lead compound (Fig. 6) resulted from a high throughput screening focused to identify compounds capable of inhibiting all three Akt isozymes, and was found to be selective over PKA, PKC and SGK (81).

The 5,6-diphenyl-pyrazin-2(1H)-one scaffold emerged as an analog of the 2,3-diphenylquinoxaline template and was used to develop potent selective inhibitors for Akt1 and Akt2 (81). Imidazoquinoxaline also proved to be a good template for the design of allosteric Akt inhibitors (79).

The transformation of the core 1,4-quinoxaline with a naphthyridine scaffold improved the compounds basicity and therefore increased polarity and the solubility (82). The introduction of the naphthyridine ring in a tricyclic structure significantly improved Akt 2 inhibition and cellular activities (83). MK-2206 
<smiles>CC(C)(N)c1ccc(-c2nc3ccccc3nc2-c2ccccc2)cc1</smiles>

2-[4-(2-aminoprop-2-yl)phenyl]-3-phenylquinoxaline<smiles>c1ccc(-c2cc3c(ccn4cnnc34)nc2-c2ccc(CC3CCC(c4n[nH]c(-c5ccccn5)n4)CC3)cc2)cc1</smiles>

MK-2206

Figure 6. Structure of MK-2206 and the 2,3-diphenylquinoxaline lead.

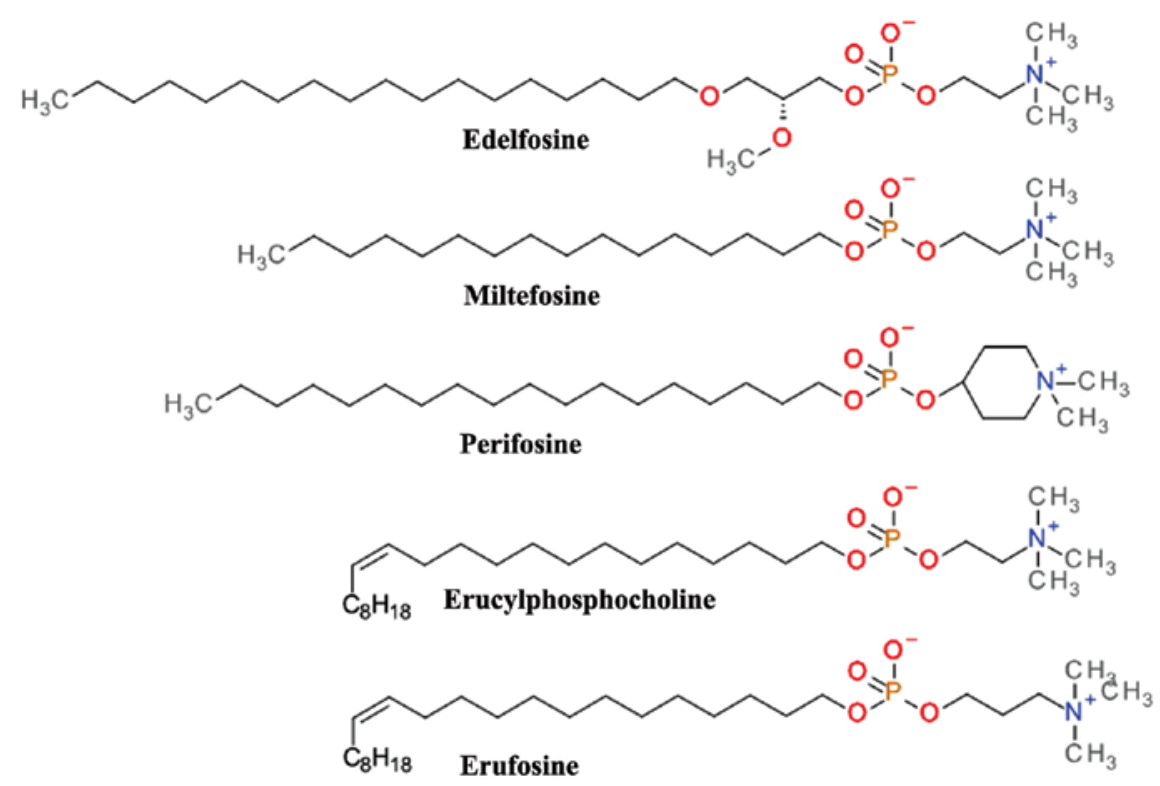

Figure 7. Chemical structure of various alkylphospholipid derivatives.

is a triazolo[3,4- $f][1,6]$ naphthyridin-3(2H)-one derivative (Fig. 6), is an orally active, highly potent and selective inhibitor of all three Akt isoforms, resulting in decreased p-Akt Thr308 and p-Akt Ser473 levels, and consequently, in the reduction of the phosphorylation of the downstream targets, GSK-3 $\beta$, PRAS40, FoxO1/FoxO3a, and Bad (84). It binds in a pocket formed at the interface of the catalytically active kinase domain and the regulatory $\mathrm{PH}$ domain locking the kinase in a closed conformation and preventing the adaptation of the active state (85).

MK-2206 induces G1-phase cell-cycle arrest and increased apoptosis, accompanied by pro-caspase cleavage in a concentration-dependent manner (86). Oxidation mediated by CYP3A4 is the primary elimination pathway (87). In preclinical experiments, MK-2206 demonstrated significant synergy when combined with doxorubicin, camptothecin (topoisomerase inhibitors), gemcitabine and 5-fluorouracil (antimetabolites), carboplatin (DNA cross-linker), erlotinib (EGFR) and lapatinib (dual EGFR/HER2 inhibitor) in lung NCI-H460 or ovarian A2780 cancer cell lines (84). MK-2206 has been extensively investigated, alone or in combination, in a considerable number of phase I or II clinical trials. Several phase I studies are evaluating MK-2206 alone or in addition to HER inhibitors, such as trastuzumab or lapatinib, in various types of breast cancer (88). The clinical evaluation of MK-2206 for the treatment of acute myelogenous leukemia proved to be largely unsatisfactory (89). The combination of MK-2206 and selumetinib, a MEK1/2 inhibitor, did not achieved the desired level of clinical activity in patients with advanced colorectal cancer (90).

Alkylphospholipids (ALPS). Structurally based on the scaffold of lysophosphatidylcholine, ALPs have a long hydrocarbon chain that allows easy partitioning into the plasma membrane of cells and thus accumulation into cell membranes (91). They kill tumor cells by the induction apoptotic and non-apoptotic cell death, and indirectly by interference with the PH domain of Akt and disrupting critical signal transduction pathways (92). ALPs (Fig. 7) prevent plasma membrane recruitment of the $\mathrm{PH}$ domain of Akt by disrupting membrane microdomains and/or by displacing its natural ligands from the PH domain. The result is that Akt is no longer capable of adopting the favorable conformation for its phosphorylation and activation (93).

Edelfosine (1-O-octadecy-2-O-methyl-rac-glycero-3phosphocholine, Et-18- $\left.\mathrm{OCH}_{3}\right)$ is one of the first synthetic analogues of lysophosphatidylcholine (94) which has shown promising anti-proliferative effects in both in vivo and in vitro models. Cells treated with edelfosine exhibited a marked and rapid decrease in p-Akt Ser473 levels, coupled with a reduction in the phosphorylation levels of mTOR (p-mTOR) (95). Its clinical use is limited by the high toxicity and low 
selectivity (96). The thioether analog of edelfosine, ilmofosine (BM 41.440) has demonstrated dose-dependent in vivo and in vitro antitumor activity in various solid tumor models. The gastrointestinal toxicity is dose-limiting and limits its clinical use (97).

The glycerol moiety in ALP has proven to be not essential for the antitumor activity and a second generation containing a phosphoester chain was designed and synthesized. Miltefosine (hexadecylphosphocholine, HePC) was evaluated asan oral therapy in clinical studies against soft tissue sarcomas (98) and advanced colorectal cancer (99); however, the doses required for the antitumor effects were too toxic. Miltefosine, either used alone or in conjunction with other therapies, proved to be effective and tolerable as a local treatment for cutaneous breast cancer (100). The clinical use of miltefosine is restricted to topical application due to hemolytic toxicity upon intravenous application. Miltefosine has demonstrated very good activity against various parasite species and is one of the few therapeutic solutions for visceral and cutaneous leishmaniasis (101).

The replacement of the choline moiety of miltefosine with a piperidine scaffold resulted in D-21266 (perifosine), a compound with a better metabolic stability, and a significantly improved gastrointestinal tract tolerance. Perifosine has displayed significant anti-proliferative activity and triggers apoptosis in vitro and in vivo in several human tumor model systems. Perifosine has been tested in several clinical trials against a large variety of tumors. As a single therapy, perifosine proved useful only in sarcoma and Waldenstrom macroglobulinemia. It is currently in clinical development for the treatment of colorectal cancer in combination with capecitabine and of multiple myeloma in combination with bortezomib and dexamethasone or in combination with lenalidomide and dexamethasone (102). Perifosine has been tested in combination with sorafenib, sunitinib, paclitaxel, docetaxel, lenalinomide or gemcitabine in various other types of cancer (91).

Erucylphosphocholine (ErPC) is a long chain and unsaturated homologue of miltefosine which causes it to associate in aqueous environments as non-haemolytic lamellar rather than micellar structures making it suitable for intravenous administration (103). Its clinical use is difficult due to the poor solubility in aqueous solutions (93). The search for structural analogues with improved solubility properties resulted in Erufosine (ErPC3, erucylphosphohomocholine) (103). Both ErPC and ErPC3 are superior to other ALPs in their ability to cross the blood-brain barrier and accumulate in brain tissue and constitute promising candidates for glioblastoma therapy (104).

ErPC and ErPC3 have been tested in various other cancer types of cancer, including acute myeloid leukemia, chronic lymphocytic leukemia, colorectal cancer and oral squamous cell carcinoma (105). Preclinical data suggest that ErPC and ErPC3 have additive or synergistic effects when combined with ionizing radiation and may be used with radiation therapy to overcome resistance to standard treatment $(104,106)$.

Indole-3-carbinol and analogues. Indole-3-carbinol is a natural compound found in the Brassica species with average anti-proliferative effects and chemopreventive activity against chemically-induced tumors in various rodent models through the inactivation of Akt kinase (107). The main disadvantage of indole-3-carbinol is its low chemical stability, under acidic conditions being converted to 3,3'-diindolylmethane which is considered responsible for its biological effects in vivo (108).

In pursuit of compounds with better stability, 3-chloroacetylindole was developed as a potent ATP non-competitive inhibitor of Aktl and Akt2, and has been shown to suppress cell growth and induce apoptosis both in vitro and in vivo experiments (109).

Based on the structure of diindolylmethane, a novel class of indole analogs were developed in order to optimize its anticancer effects. The most promising of these analogs, an indolo[2,3- $b]$ carbazole derivative, has exhibited potent oral anticancer activity against various types of cancer and no significant toxicity (110). SR13668 has been shown to have no adverse effects on fasting glucose levels or body weight in mice treated with doses of up to $500 \mathrm{mg} / \mathrm{kg}$ for 14 days (110). Preclinical pharmacokinetic studies found low bioavailability in rats, dogs and monkeys due to the limited aqueous solubility and expected high permeability through biological membranes (111). SR13668 was investigated in a clinical trial on healthy volunteers to assess the formulation effect on the bioavailability after oral administration (112).

OSU-A9 is an indole-3-carbinol derivative with better chemical stability that has been shown to inhibit Akt signaling in MCF-7 cells, as demonstrated by the concomitant dephosphorylation of Akt and two downstream kinase substrates, GSK-3 $\beta$ and IKK $\alpha$. This new derivative was also found to inhibit the nuclear factor- $\kappa \mathrm{B}$ signaling pathways (113).

Sulfonamide derivatives. A three-dimensional virtual screening based on the Akt1 PH domain structure led to the development of compound PH-316, a sulfadiazine derivative (Fig. 8), which inhibited Akt and HT-29 cell proliferation. However, it failed to achieve the blood concentration required to inhibit Akt in animal models, due to the rapid metabolism of the azo bond (114). In order to improve the anticancer profile of PH-316, a larger in silico study was performed and four scaffolds were identified. Several structural modifications led to PHT-427 (4-dodecyl- $N$-(1,3,4-thiadiazol-2-yl) benzenesulfonamide), a potent Akt inhibitor with an $\mathrm{IC}_{50}$ of $6.3 \pm 0.9 \mu \mathrm{mol} / 1$ in Panc-1 cells and a strong inducer of apoptosis at $20 \mu \mathrm{mol} / \mathrm{l}(115)$. PHT-427 inhibited the growth of various human tumor xenografts in immunodeficient mice following oral administration. It showed synergic antitumor activity with paclitaxel and gemcitabine in a Panc-1 tumors, with erlotinib in a non-small-cell lung cancers and with paclitaxel in breast cancer (116).

Thiourea derivatives. High-throughput fluorescence polarization binding assay based on a recombinant fragment of human Akt1 identified two inhibitors of PIP3/PH domain binding, which were termed PIT-1 and PIT-2. They also inhibited, although with lower affinity, the binding of PIP3 to the PH domains of PDK1, general receptor for phosphoinositides isoform 1 (GRP1) and ARNO (117). Structural analysis demonstrated that thiourea and hydroxyl groups are critical for the anticancer activity. Due to the limited aqueous solubility of PIT-1, the dimethyl analog, DM-PIT-1 (Fig. 8), was developed (118). In a study focusing on the synthesis of new pyrazole derivatives based on the tenovins scaffold, we obtained N-[(1-methyl-1H-pyrazol-4-yl) 
<smiles>CCCCCCCCCCCCc1ccc(S(=O)(=O)Nc2nncs2)cc1</smiles>

Figure 8. Representative sulfonamide derivatives and thiourea based compounds.<smiles>Cn1nc(N)c2cn3c4c(ncnc41)C2OC(CO)C3O</smiles>

Triciribine<smiles>CC(=O)Nc1cccc(-c2ccc3nc(-c4cccnc4N)n(-c4ccc(CNC(=O)c5cccc(F)c5)cc4)c3n2)c1</smiles>

3-phenyl-3H-imidazo[4,5-b]pyridine derivative

Figure 9. Purine based Akt inhibitors.

carbonyl]-N'-(3-bromophenyl)-thiourea as an apoptosis agent and biological screening suggested that it can inhibit Akt in a similar manner with PIT-1 (119).

Purine derivatives. Screening of the National Cancer Institute (NCI) Diversity Set led to the identification of API-2 [(Triciribine (TCN), NSC 154020] that potently inhibited Akt signaling in human cancer cells, leading to the inhibition of cell growth and the induction of apoptosis (120). TCN is a tricyclic purine nucleoside derivative (Fig. 9) that is metabolically activated inside cells by adenosine kinase to its monophosphate active analog, TCN-P (121). Surface plasmon resonance and nuclear magnetic resonance spectroscopy have demonstrated that TCN-P, but not TCN, binds to the PH domain of Akt in the vicinity of the PIP3 binding pocket, thereby preventing Akt phosphorylation and subsequent activation. The proposed mechanism of TCN-P Akt inhibition is by preventing PIP3 from recruiting Akt to the plasma membrane, either by competing with PIP3 for binding to PH domain or by binding to region that induces conformational changes that hinder PIP3 activation (122). Treatment of T cell acute lymphocytic leukemia cells with $10 \mu \mathrm{M}$ TCN has been shown to inhibit Akt phosphorylation and its downstream signaling, causing cell cycle arrest and caspase-dependent apoptosis (123). In prostate cancer cells, TCN was shown to increase the apoptosis induced by the death receptor pathway (124). TCN and TCN-P were subjected to several clinical trials against various solid neoplasms and hematological malignancies, but their efficacy is limited due to their toxicity (121). The combination treatment of TCN with other anticancer agents proved to be a better solution than treatment with TCN alone (125).

An isosteric scaffold of adenosine, the 4-aminopyrido[2,3- $d]$ pyrimidine derivative API-1 was discovered to inhibit Akt by screening the DTP/NCI compound library in a cell-based assay. API-1 binds to the PH domain and inhibits Akt membrane translocation, leading to the inhibition of the growth of tumors with hyperactivated Akt (126). API-1 was shown to induce apoptosis in tested cancer cell lines by synergizing with TNF-related apoptosis-inducing ligand (TRAIL) (127). A series of 4-amino-pyrrolo[2,3- $d$ ]pyrimidine derivatives, closely related to API-1, were discovered in a high-throughput screening based on a newly developed fluorescence-based assay as allosteric Akt inhibitors (85). 
<smiles>C[C@@H]1O[C@@H]2CC(=O)O[C@H]2C2=C1C(=O)c1ccc([C@@H]3CC(N(C)C)[C@H](O)[C@@H](C)O3)c(O)c1C2=O</smiles><smiles>C=CC(=O)[C@H](Cc1ccccc1)NC(=O)OC(C)(C)C</smiles>

Boc-Phe-vinyl ketone

Figure 10. Representative irreversible Akt inhibitors.

A series of 3-phenyl-3H-imidazo[4,5-b]pyridine was developed as orally bioavailable potent ATP non-competitive Akt inhibitors, the best compound being the $\mathrm{N}-(4-(5-(3-$ acetamidophenyl)-2-(2-aminopyridin-3-yl)-3H-imidazo[4,5- $b]$ pyridin-3-yl)benzyl)-3-fluorobenzamide (128). Even if the imidazo[4,5-b]pyridine template is closely related to the purine ring, the structural conformation of these compounds resemble more the 2,3-diphenylquinoxalines based derivatives.

ARQ 092 was identified searching for inhibitors which use the intrinsic negative regulatory function of hydrophobic clusters in the ATP-binding cleft. ARQ 092 binds to inactive, unphosphorylated Akt1 with subnanomolar affinity and inhibits all three isoforms. In a previous study, the growth of AN3CA human endometrial tumors was markedly suppressed in xenograft models following the oral administration of ARQ 092 (129). ARQ 092 and its congener, ARQ 751, have been shown to inhibit proliferation across multiple tumor types and were most potent in leukemia, breast, endometrial and colorectal cancer cell lines (130). Only the core structure of these compounds was disclosed and consists of 3-(3-phenyl$3 H$-imidazo[4,5-b]pyridin-2-yl)pyridin-2-amines. The authors do not mention the developmental process, but most probably it involved the aforementioned N-(4-(5-(3-acetamidophenyl)2-(2-aminopyridin-3-yl)-3H-imidazo[4,5-b]pyridin-3-yl)benzyl)3-fluorobenzamide.

Derivatives with various structures. BAY 1125976 has been reported as a highly selective, potent allosteric Akt1/2 inhibitor, with strong in vitro and in vivo activity in tumor models with activated Akt signaling and in cell lines possessing the activating mutation, Akt1E17K (131). The structure of the compound was not yet disclosed.

Using in silico screening, derivatives of 3-methylxanthine, quinoline-4-carboxamide and 2-[4-(cyclohexa-1,3dien-1-yl)-1H-pyrazol-3-yl]phenol were proposed as potential leads for future development of Aktl allosteric inhibitors (132).

A series of tetracyclic triterpenoids isolated from the oleogum resin of Boswellia carterii were discovered as potent Akt inhibitors, whereas, 3-oxo-tirucallic acid is a weak inhibitor of Akt, $3 \alpha$ - and $3 \beta$ - acetoxy-tirucallic acids block Akt1 activity at concentrations below $1 \mu \mathrm{mol} / 1$. Treatment of PC-3 cells with acetoxy-tirucallic acids was shown to inhibit the phosphorylation of GSK-3 $\beta$ and reduce the nuclear levels of $\beta$-catenin and c-Myc. Molecular docking studies indicated that tirucallic acids exhibit affinity binding to the PH domain of Akt. Treatment of mice bearing xenotransplanted PC-3 tumors for 2 weeks with $10 \mu \mathrm{mol} / \mathrm{kg} 3 \beta$-acetoxy-tirucallic resulted in a significant reduction in tumor growth (133).

\section{Irreversible inhibitors}

Lactoquinomycin is a natural product isolated from the fermentation broth of Streptomyces sp. LL-AF101 that was found to selectively inhibit Akt (134). Lactoquinomycin is a pyrano-naphthoquinone antibiotic (Fig. 10) and a potent inhibitor of Akt by irreversible covalent interaction with two critical catalytic activation loop cysteines (Cys296 and Cys310) and does not interfere with the PDK1-dependent Thr308 phosphorylation (135). The proposed mechanism is a S-alkylation involving the reduction of the quinone ring to a hydroquinone and subsequent opening of the lactone ring (136). In various tumor cell models, lactoquinomycin potently inhibited the phosphorylation of Akt downstream substrates GSK-3 $\alpha / \beta$, FKHRL1 and mTOR (135). Frenolicin B is a related pyrano-naphthoquinone natural derivative with similar Akt inhibition profile (136). A similar inhibitory effect was observed for kalafungin and medermycin (136).

A phenylalanine vinyl ketone derivative (Fig. 10) was designed and synthesized as a covalent inactivator of Akt, and demonstrated potent cell growth inhibition in HCT116 and H460 cells and selective Akt inhibition by bonding to Cys310 (137). Alkylation of Cys310 by Michael acceptors was demonstrated also for 4-hydroxynonenal (138).

The 1,6-naphthyridinone and imidazo-1,2-pyridine templates were used to design Michael acceptors to target Cys296 or Cys310. The lead compound exhibited a selective profile, exclusively targeting Akt isoforms without affecting related kinases (139).

\section{Clinically relevant Akt inhibitors}

Despite the large number of compounds proven to inhibit Akt in vitro and in vivo models, only a limited number of these have entered clinical evaluation. Miltefosine is the only Akt inhibitor approved, but only for the treatment of visceral and cutaneous leishmaniasis, and not for the treatment of cancer. The compounds evaluated clinically and the status of the trials are summarized in Table II.

Based on the cellular function of Akt and on the preclinical studies of the efficacy of various Akt inhibitors, the strategy of combined therapy emerged as a major research direction. On 
Table II. Reported clinical evaluations of Akt inhibitors.

\begin{tabular}{|c|c|c|}
\hline Therapeutic regimen & Indication & Status \\
\hline GSK690693 & $\begin{array}{l}\text { Hematological neoplasia, } \\
\text { acute lymphoblastic leukemia }\end{array}$ & $\begin{array}{l}\text { Clinical development terminated } \\
\text { due to hyperglycemia }\end{array}$ \\
\hline AZD5363 monotherapy & Breast cancer, gastric cancer, prostate cancer & Phase I/phase II clinical trials \\
\hline $\begin{array}{l}\text { Afuresertib (GSK2110183) } \\
\text { monotherapy }\end{array}$ & Relapsed or refractory multiple myeloma & Phase I/phase II clinical trials \\
\hline $\begin{array}{l}\text { Afuresertib (GSK2110183) } \\
\text { in combination with bortezomib } \\
\text { or dexamethasone }\end{array}$ & Relapsed or refractory multiple myeloma & Phase I/Phase II clinical trials \\
\hline $\begin{array}{l}\text { Uprosertib (GSK2141795) } \\
\text { monotherapy }\end{array}$ & Relapsed or refractory multiple myeloma & Phase I/phase II clinical trials \\
\hline $\begin{array}{l}\text { Uprosertib (GSK2141795) in } \\
\text { combination with trametinib }\end{array}$ & Relapsed or refractory multiple myeloma & Phase I/phase II clinical trials \\
\hline $\begin{array}{l}\text { Ipatasertib (GDC-0068, RG7440) } \\
\text { monotherapy }\end{array}$ & Triple-negative breast cancer & Phase I/phase II clinical trials \\
\hline $\begin{array}{l}\text { MK-2206 in combination } \\
\text { with gefitinib or erlotinib }\end{array}$ & Advanced non-small-cell lung carcinoma & Phase I/phase II clinical trials \\
\hline MK-2206 monotherapy & Acute myelogenous leukemia & $\begin{array}{l}\text { Unsatisfactory clinical results } \\
\text { Usage limited to topical application } \\
\text { due to hemolytic toxicity } \\
\text { after intravenous injection }\end{array}$ \\
\hline $\begin{array}{l}\text { MK-2206 in combination } \\
\text { with selumetinib }\end{array}$ & Colorectal carcinoma & $\begin{array}{l}\text { Unsatisfactory clinical results } \\
\text { Similar toxicity as for monotherapy }\end{array}$ \\
\hline MK-2206 monotherapy & $\begin{array}{l}\text { Non-cancerous disease } \\
\text { (visceral and cutaneous leishmaniasis) }\end{array}$ & Early clinical evaluation \\
\hline TCN or TCN-P monotherapy & Solid tumors, hematological malignancies & Clinical efficacy limited due to toxicity \\
\hline
\end{tabular}

Table III. Reported preclinical combinations with other therapeutic modalities.

\begin{tabular}{|c|c|c|}
\hline Akt inhibitor & Combination with & Action \\
\hline A-674563, A-443654 & Microtubule inhibitor (paclitaxel) & Inhibition of Akt through PKA \\
\hline Afuresertib (GSK2110183) & $\begin{array}{l}\text { Proteasome inhibitor (bortezomib) } \\
\text { Anti-inflammatory drug (dexamethasone) }\end{array}$ & Inhibition of Akt1, Akt2, Akt3 \\
\hline Uprosertib (GSK2141795) & MEK1, MEK2 kinase inhibitor (trametinib) & Inhibition of Akt1, Akt2, Akt3 \\
\hline MK-2206 & $\begin{array}{l}\text { Topoisomerase inhibitors (doxorubicin, camptothecin) } \\
\text { Nucleotide analogues (gemcitabine, 5-FU) } \\
\text { DNA cross-linker (carboplatin) } \\
\text { EGFR inhibitors (erlotinib, gefitinib, ZD1839, trastuzumab) } \\
\text { Kinase inhibitors (lapatinib, selumetinib) }\end{array}$ & G1 arrest, apoptosis induction \\
\hline Perifosine (D-21266) & Capecitabine (prodrug of nucleotide analogue 5-FU) & $\begin{array}{l}\text { Inhibition of p-mTOR, } \\
\text { apoptosis induction }\end{array}$ \\
\hline $\begin{array}{l}\text { Erucylphosphocholine (ErPC), } \\
\text { erufosine (ErPC3, } \\
\text { erucylphosphohomocholine) }\end{array}$ & Radiation therapy & Inhibition of p-mTOR \\
\hline TCN, TCN-P & Nucleotide analogue (gemcitabine) & Inhibition of p-Akt \\
\hline
\end{tabular}

the other hand, Akt inhibitors have been shown to significantly improve the therapeutic outcome of traditional anticancer drugs. The preclinical tests of several Akt inhibitors as combinative therapy are summarized in Table III. 


\section{Potential biomarker for Akt inhibitors}

In the era of precision medicine identifying predictive biomarkers, therapy with targeted agents has become a major goal of translational research. Therefore, potential biomarkers for treatment with Akt inhibitors would facilitate the design of clinical trials and would accelerate the introduction of these compounds to clinical practice. In this regard, the observation that sensitivity to Akt-specific inhibitors is dependent upon the activation of the PI3K/Akt/mTOR pathway suggests that biomarkers in this pathway may by predictive for treatment with Akt inhibitors (140). Similarly, experiments using cell lines with PIK3CA or PTEN alterations have demonstrated increased activity for all MK-2206, AZD5363 and GDC-0068 compounds (63,141,142).

In the clinic, early-phase trials with MK-2206 and ipatasertib support the hypothesis that AKT inhibitors do possess activity against tumors with PTEN deficiency. Objective responses have been reported in patients with PTEN-deficient metastatic pancreatic and colorectal cancer $(143,144)$. In addition to the loss of PTEN, clinical evidence suggests that patients with PIK3CA-mutant tumors may benefit from treatment with Akt inhibitors. For example, in phase I trials of single-agent ipatasertib and AZD5363, objective response and clinical benefit were observed in patients with PIK3CA-mutant colorectal cancer (145), as well as gynecological malignancies (cervical and endometrial cancer) with PIK3CA mutations (146). In conclusion, analysis for somatic alteration in PTEN or PIK3CA mutation may serve as a potent biomarker to therapy with Akt inhibitors.

\section{Conclusions}

Akt modulates and regulates the function of numerous substrates and is the key factor in cell survival and growth mechanism. A plethora of studies supports the role of Akt as a well validated target for drug development. In spite of modern drug discovery techniques and increasing knowledge regarding Akt functions and activation, no Akt inhibitor has been yet approved for oncologic use. This is further coupled with a relatively low number of compounds that have been included in clinical trials.

The drug discovery process is hindered by a high degree of structural similarity between Akt isoforms, especially in the catalytic domain, and their considerable structural analogy to the AGC kinase family. The use of alternative approaches employing allosteric inhibitors of Akt produced compounds with better selectivity and efficacy.

All the major components of the Akt pathway, consisting of PI3Ks, PDK1, Akt and mTOR, are the focus of intensive research for targeted cancer therapy (32). However, thus far a limited number of drugs has emerged from this approach.

Clinical trials with MK-2206 and GDC-0068 support the hypothesis that Akt inhibitors will be most useful in tumors with PTEN deficiency and PIK3 mutations (147). However, most Akt inhibitors display a rather limited clinical activity as single agents. This clearly emphasizes the importance of combinatorial treatments for better therapeutic perspective of Akt inhibitors.

\section{Acknowledgements}

The authors acknowledge the financial support offered by Romanian National Authority for Scientific Research,
UEFISCDI, through grant PN-II-PCCA-2 no. 136/2012 and grant PN-II-RU-TE-2014-4-1670, no. 342/2015.

\section{References}

1. Ferlay J, Soerjomataram I, Dikshit R, Eser S, Mathers C, Rebelo M, Parkin DM, Forman D and Bray F: Cancer incidence and mortality worldwide: Sources, methods and major patterns in GLOBOCAN 2012. Int J Cancer 136: E359-E386, 2015.

2. Siegel R, Ma J, Zou Z and Jemal A: Cancer statistics, 2014. CA Cancer J Clin 64: 9-29, 2014.

3. Steelman LS, Stadelman KM, Chappell WH, Horn S, Bäsecke J, Cervello M, Nicoletti F, Libra M, Stivala F, Martelli AM, et al: Akt as a therapeutic target in cancer. Expert Opin Ther Targets 12: 1139-1165, 2008.

4. Bellacosa A, Kumar CC, Di Cristofano A and Testa JR: Activation of AKT kinases in cancer: Implications for therapeutic targeting. Adv Cancer Res 94: 29-86, 2005.

5. Arcaro A and Guerreiro AS: The phosphoinositide 3-kinase pathway in human cancer: Genetic alterations and therapeutic implications. Curr Genomics 8: 271-306, 2007.

6. Mitsiades CS, Mitsiades N and Koutsilieris M: The Akt pathway: Molecular targets for anti-cancer drug development. Curr Cancer Drug Targets 4: 235-256, 2004.

7. Altomare DA and Testa JR: Perturbations of the AKT signaling pathway in human cancer. Oncogene 24: 7455-7464, 2005.

8. Song G, Ouyang $\mathrm{G}$ and Bao S: The activation of Akt/PKB signaling pathway and cell survival. J Cell Mol Med 9: 59-71, 2005.

9. Martelli AM, Tabellini G, Bressanin D, Ognibene A, Goto K, Cocco L and Evangelisti C: The emerging multiple roles of nuclear Akt. Biochim Biophys Acta - Mol. Cell Res 1823: 2168-2178, 2012

10. Arencibia JM, Pastor-Flores D, Bauer AF, Schulze JO and Biondi RM: AGC protein kinases: From structural mechanism of regulation to allosteric drug development for the treatment of human diseases. Biochim Biophys Acta 1834: 1302-1321, 2013.

11. Davis WJ, Lehmann PZ and Li W: Nuclear PI3K signaling in cell growth and tumorigenesis. Front Cell Dev Biol 3: 24, 2015.

12. Sasaki T, Yamashita Y and Kuniyasu H: AKT plays a crucial role in gastric cancer (Review). Oncol Lett 10: 607-611, 2015.

13. Shayesteh L, Lu Y, Kuo W-L, Baldocchi R, Godfrey T, Collins C, Pinkel D, Powell B, Mills GB and Gray JW: PIK3CA is implicated as an oncogene in ovarian cancer. Nat Genet 21: 99-102, 1999.

14. Levine DA, Bogomolniy F, Yee CJ, Lash A, Barakat RR, Borgen PI and Boyd J: Frequent mutation of the PIK3CA gene in ovarian and breast cancers. Clin Cancer Res 11: 2875-2878, 2005.

15. Andjelković M, Alessi DR, Meier R, Fernandez A, Lamb NJ, Frech M, Cron P, Cohen P, Lucocq JM and Hemmings BA: Role of translocation in the activation and function of protein kinase B. J Biol Chem 272: 31515-31524, 1997.

16. Carnero A and Paramio JM: The PTEN/PI3K/AKT Pathway in vivo, Cancer Mouse Models. Front Oncol 4: 252, 2014.

17. Conus NM, Hannan KM, Cristiano BE, Hemmings BA and Pearson RB: Direct identification of tyrosine 474 as a regulatory phosphorylation site for the Akt protein kinase. J Biol Chem 277: 38021-38028, 2002.

18. Legate KR, Montañez E, Kudlacek O and Fässler R: ILK, PINCH and parvin: The tIPP of integrin signalling. Nat Rev Mol Cell Biol 7: 20-31, 2006.

19. Jhaveri K and Modi S: Ganetespib: Research and clinical development. Onco Targets Ther 8: 1849-1858, 2015.

20. O'Neill AK, Niederst MJ and Newton AC: Suppression of survival signalling pathways by the phosphatase PHLPP. FEBS J 280: 572-583, 2013.

21. Fresno Vara JA, Casado E, de Castro J, Cejas P, Belda-Iniesta C and González-Barón M: PI3K/Akt signalling pathway and cancer. Cancer Treat Rev 30: 193-204, 2004.

22. Altomare DA and Khaled AR: Homeostasis and the importance for a balance between AKT/mTOR activity and intracellular signaling. Curr Med Chem 19: 3748-3762, 2012.

23. Cohen MM Jr: The AKT genes and their roles in various disorders. Am J Med Genet A 161 A: 2931-2937, 2013.

24. Emamian ES: AKT/GSK3 signaling pathway and schizophrenia. Front Mol Neurosci 5: 33, 2012.

25. Mackenzie RWA and Elliott BT: Akt/PKB activation and insulin signaling: A novel insulin signaling pathway in the treatment of type 2 diabetes. Diabetes Metab Syndr Obes 7: 55-64, 2014. 
26. Osorio-Fuentealba $\mathrm{C}$ and Klip A: Dissecting signalling by individual $\mathrm{Akt} / \mathrm{PKB}$ isoforms, three steps at once. Biochem J 470: e13-e16, 2015.

27. Easton RM, Cho H, Roovers K, Shineman DW, Mizrahi M, Forman MS, Lee VM, Szabolcs M, de Jong R, Oltersdorf T, et al: Role for Akt3/protein kinase Bgamma in attainment of normal brain size. Mol Cell Biol 25: 1869-1878, 2005.

28. West KA, Castillo SS and Dennis PA: Activation of the PI3K/Akt pathway and chemotherapeutic resistance. Drug Resist Updat 5: 234-248, 2002

29. Candido S, Rapisarda V, Marconi A, Malaponte G, Bevelacqua V, Gangemi P, Scalisi A, McCubrey JA, Maestro R, Spandidos DA, et al: Analysis of the $B-R a f^{V 600 \mathrm{E}}$ mutation in cutaneous melanoma patients with occupational sun exposure. Oncol Rep 31: 1079-1082, 2014.

30. Shi Y, Liu X, Han EK, Guan R, Shoemaker AR, Oleksijew A, Woods KW, Fisher JP, Klinghofer V, Lasko L, et al: Optimal classes of chemotherapeutic agents sensitized by specific small-molecule inhibitors of akt in vitro and in vivo. Neoplasia 7 : 992-1000, 2005.

31. Hafsi S, Pezzino FM, Candido S, Ligresti G, Spandidos DA, Soua Z, McCubrey JA, Travali S and Libra M: Gene alterations in the PI3K/PTEN/AKT pathway as a mechanism of drug-resistance (Review). Int J Oncol 40: 639-644, 2012.

32. Carnero A: The PKB/AKT pathway in cancer. Curr Pharm Des 16: 34-44, 2010.

33. Nagata Y, Lan K-H, Zhou X, Tan M, Esteva FJ, Sahin AA, Klos KS, Li P, Monia BP, Nguyen NT, et al: PTEN activation contributes to tumor inhibition by trastuzumab, and loss of PTEN predicts trastuzumab resistance in patients. Cancer Cell 6: 117-127, 2004.

34. Fujita T, Doihara H, Washio K, Kawasaki K, Takabatake D, Takahashi H, Tsukuda K, Ogasawara Y and Shimizu N: Proteasome inhibitor bortezomib increases PTEN expression and enhances trastuzumab-induced growth inhibition in trastuzumab-resistant cells. Anticancer Drugs 17: 455-462, 2006.

35. Olaru OT, Niţulescu GM, Orțan A and Dinu-Pîrvu CE: Ethnomedicinal, Phytochemical and Pharmacological Profile of Anthriscus sylvestris as an Alternative Source for Anticancer Lignans. Molecules 20: 15003-15022, 2015.

36. Peuhu E, Rivero-Müller A, Stykki H, Torvaldson E, Holmbom T, Eklund P, Unkila M, Sjöholm R and Eriksson JE: Inhibition of Akt signaling by the lignan matairesinol sensitizes prostate cancer cells to TRAIL-induced apoptosis. Oncogene 29: 898-908, 2010

37. Shoji K, Oda K, Nakagawa S, Hosokawa S, Nagae G, Uehara Y, Sone K, Miyamoto Y, Hiraike H, Hiraike-Wada O, et al: The oncogenic mutation in the pleckstrin homology domain of AKT1 in endometrial carcinomas. Br J Cancer 101: 145-148, 2009.

38. Rychahou PG, Kang J, Gulhati P, Doan HQ, Chen LA, Xiao SY Chung DH and Evers BM: Akt2 overexpression plays a critical role in the establishment of colorectal cancer metastasis. Proc Natl Acad Sci USA 105: 20315-20320, 2008.

39. Graff JR, Konicek BW, McNulty AM, Wang Z, Houck K, Allen S, Paul JD, Hbaiu A, Goode RG, Sandusky GE, et al: Increased AKT activity contributes to prostate cancer progression by dramatically accelerating prostate tumor growth and diminishing p27Kip1 expression. J Biol Chem 275: 24500-24505, 2000.

40. Altomare DA, Tanno S, De Rienzo A, Klein-Szanto AJ, Tanno S, Skele KL, Hoffman JP and Testa JR: Frequent activation of AKT2 kinase in human pancreatic carcinomas. J Cell Biochem 87: 470-476, 2002

41. Lin HP, Lin CY, Huo C, Jan YJ, Tseng JC, Jiang SS, Kuo YY, Chen SC, Wang CT, Chan TM, et al: AKT3 promotes prostate cancer proliferation cells through regulation of Akt, B-Raf, and TSC1/TSC2. Oncotarget 6: 27097-27112, 2015.

42. Cristiano BE, Chan JC, Hannan KM, Lundie NA, Marmy-Conus NJ, Campbell IG, Phillips WA, Robbie M, Hannan RD and Pearson RB: A specific role for AKT3 in the genesis of ovarian cancer through modulation of $\mathrm{G}(2)-\mathrm{M}$ phase transition. Cancer Res 66: 11718-11725, 2006.

43. Mattmann ME, Stoops SL and Lindsley CW: Inhibition of Akt with small molecules and biologics: Historical perspective and current status of the patent landscape. Expert Opin Ther Pat 21: $1309-1338,2011$

44. Kumar CC and Madison V: AKT crystal structure and AKT-specific inhibitors. Oncogene 24: 7493-7501, 2005.

45. Böckmann S and Nebe B: The in vitro effects of $\mathrm{H}-89$, a specific inhibitor of protein kinase $\mathrm{A}$, in the human colonic carcinoma cell line Caco-2. Eur J Cancer Prev 12: 469-478, 2003.
46. Reuveni H, Livnah N, Geiger T, Klein S, Ohne O, Cohen I, Benhar M, Gellerman G and Levitzki A: Toward a PKB inhibitor: Modification of a selective PKA inhibitor by rational design. Biochemistry 41: 10304-10314, 2002.

47. Breitenlechner CB, Wegge T, Berillon L, Graul K, Marzenell K, Friebe WG, Thomas U, Schumacher R, Huber R, Engh RA, et al: Structure-based optimization of novel azepane derivatives as PKB inhibitors. J Med Chem 47: 1375-1390, 2004.

48. Murray AJ: Pharmacological PKA inhibition: All may not be what it seems. Sci Signal 1: re4-re4, 2008

49. Heerding DA, Rhodes N, Leber JD, Clark TJ, Keenan RM, Lafrance LV, Li M, Safonov IG, Takata DT, Venslavsky JW, et al: Identification of 4-(2-(4-amino-1,2,5-oxadiazol-3-yl)-1-ethyl-7$\{[(3 \mathrm{~S})-3$-piperidinylmethyl]oxy\}-1H-imidazo[4,5-c]pyridin-4-yl) -2-methyl-3-butyn-2-ol (GSK690693), a novel inhibitor of AKT kinase. J Med Chem 51: 5663-5679, 2008.

50. Levy DS, Kahana JA and Kumar R: AKT inhibitor, GSK690693, induces growth inhibition and apoptosis in acute lymphoblastic leukemia cell lines. Blood 113: 1723-1729, 2009.

51. Carol H, Morton CL, Gorlick R, Kolb EA, Keir ST, Reynolds CP, Kang MH, Maris JM, Billups C, Smith MA, et al: Initial testing (stage 1) of the Akt inhibitor GSK690693 by the pediatric preclinical testing program. Pediatr Blood Cancer 55: 1329-1337, 2010.

52. Crouthamel MC, Kahana JA, Korenchuk S, Zhang SY, Sundaresan G, Eberwein DJ, Brown KK and Kumar R: Mechanism and management of AKT inhibitor-induced hyperglycemia. Clin Cancer Res 15: 217-225, 2009.

53. Donald A, McHardy T, Rowlands MG, Hunter LJ, Davies TG, Berdini V, Boyle RG, Aherne GW, Garrett MD and Collins I: Rapid evolution of 6-phenylpurine inhibitors of protein kinase B through structure-based design. J Med Chem 50: 2289-2292, 2007.

54. Caldwell JJ, Davies TG, Donald A, McHardy T, Rowlands MG, Aherne GW, Hunter LK, Taylor K, Ruddle R, Raynaud FI, et al: Identification of 4-(4-aminopiperidin-1-yl)-7H-pyrrolo[2,3-d] pyrimidines as selective inhibitors of protein kinase B through fragment elaboration. J Med Chem 51: 2147-2157, 2008.

55. Yap TA, Walton MI,Hunter L-JK, Valenti M, de Haven Brandon A, Eve PD, Ruddle R, Heaton SP, Henley A, Pickard L, et al: Preclinical pharmacology, antitumor activity, and development of pharmacodynamic markers for the novel, potent AKT inhibitor CCT128930. Mol Cancer Ther 10: 360-371, 2011.

56. Freeman-Cook KD, Autry C, Borzillo G, Gordon D, Barbacci-Tobin E, Bernardo V, Briere D, Clark T, Corbett M, Jakubczak J, et al: Design of selective, ATP-competitive inhibitors of Akt. J Med Chem 53: 4615-4622, 2010.

57. Lippa B, Pan G, Corbett M, Li C, Kauffman GS, Pandit J, Robinson S, Wei L, Kozina E, Marr ES, et al: Synthesis and structure based optimization of novel Akt inhibitors. Bioorg Med Chem Lett 18: 3359-3363, 2008.

58. McHardy T, Caldwell JJ, Cheung KM, Hunter LJ, Taylor K, Rowlands M, Ruddle R, Henley A, de Haven Brandon A, Valenti M, et al: Discovery of 4-amino-1-(7H-pyrrolo[2,3-d] pyrimidin-4-yl)piperidine-4-carboxamides as selective, orally active inhibitors of protein kinase B (Akt). J Med Chem 53: 2239-2249, 2010

59. Addie M, Ballard P, Buttar D, et al: Discovery of 4-amino-N[(1S)-1-(4-chlorophenyl)-3-hydroxypropyl]-1-(7H-pyrrolo[2,3-d] pyrimidin-4-yl)piperidine-4-carboxamide (AZD5363), an orally bioavailable, potent inhibitor of Akt kinases. J Med Chem 56 2059-2073, 2013.

60. Crafter C, Vincent JP, Tang E, Dudley P, James NH, Klinowska T and Davies BR: Combining AZD8931, a novel EGFR/HER2/HER3 signalling inhibitor, with AZD5363 limits AKT inhibitor induced feedback and enhances antitumour efficacy in HER2-amplified breast cancer models. Int J Oncol 47: 446-454, 2015.

61. Lamoureux F and Zoubeidi A: Dual inhibition of autophagy and the AKT pathway in prostate cancer. Autophagy 9: 1119-1120, 2013.

62. Blake JF, Xu R, Bencsik JR, Xiao D, Kallan NC, Schlachter S, Mitchell IS, Spencer KL, Banka AL, Wallace EM, et al: Discovery and preclinical pharmacology of a selective ATP-competitive Akt inhibitor (GDC-0068) for the treatment of human tumors. J Med Chem 55: 8110-8127, 2012.

63. Lin J, Sampath D, Nannini MA, Lee BB, Degtyarev M, Oeh J, Savage H, Guan Z, Hong R, Kassees R, et al: Targeting activated Akt with GDC-0068, a novel selective Akt inhibitor that is efficacious in multiple tumor models. Clin Cancer Res 19: 1760-1772, 2013. 
64. Kim S, Tan AR, Im S, Villanueva R, Valero V, Saura C, Oliveira M, Isakoff SJ, Singel SM and Dent RA: LOTUS: A randomized, phase II, multicenter, placebo-controlled study of ipatasertib (Ipat, GDC-0068), an inhibitor of Akt, in combination with paclitaxel (Pac) as front-line treatment for patients (pts) with metastatic triple-negative breast cancer (TNBC). ASCO Meet Abstr 33: TPS1111, 2015.

65. Luo Y, Shoemaker AR, Liu X, Woods KW, Thomas SA, de Jong R, Han EK, Li T, Stoll VS, Powlas JA, et al: Potent and selective inhibitors of Akt kinases slow the progress of tumors in vivo. Mol Cancer Ther 4: 977-986, 2005.

66. Woods KW, Fischer JP, Claiborne A, Li T, Thomas SA, Zhu GD, Diebold RB, Liu X, Shi Y, Klinghofer V, et al: Synthesis and SAR of indazole-pyridine based protein kinase B/Akt inhibitors. Bioorg Med Chem 14: 6832-6846, 2006.

67. Lin H, Yamashita DS, Xie R, Zeng J, Wang W, Leber J, Safonov IG, Verma S, Li M, Lafrance L, et al: Tetrasubstituted pyridines as potent and selective AKT inhibitors: Reduced CYP450 and hERG inhibition of aminopyridines. Bioorg Med Chem Lett 20: 684-688, 2010.

68. Ko JH, Yeon SW, Ryu JS, Kim TY, Song EH, You HJ, Park RE and Ryu CK: Synthesis and biological evaluation of 5-arylamino-6-chloro-1H-indazole-4,7-diones as inhibitors of protein kinase B/Akt. Bioorg Med Chem Lett 16: 6001-6005, 2006.

69. Bencsik JR, Xiao D, Blake JF, Kallan NC, Mitchell IS, Spencer KL, Xu R, Gloor SL, Martinson M, Risom T, et al: Discovery of dihydrothieno- and dihydrofuropyrimidines as potent pan Akt inhibitors. Bioorg Med Chem Lett 20: 7037-7041, 2010.

70. Saxty G, Woodhead SJ, Berdini V, Davies TG, Verdonk ML, Wyatt PG, Boyle RG, Barford D, Downham R, Garrett MD, et al: Identification of inhibitors of protein kinase B using fragment-based lead discovery. J Med Chem 50: 2293-2296, 2007.

71. Grimshaw KM, Hunter L-JK, Yap TA, Heaton SP, Walton MI, Woodhead SJ, Fazal L, Reule M, Davies TG, Seavers LC, et al: AT7867 is a potent and oral inhibitor of AKT and p70 S6 kinase that induces pharmacodynamic changes and inhibits human tumor xenograft growth. Mol Cancer Ther 9: 1100-1110, 2010.

72. Yap TA, Walton MI, Grimshaw KM, Te Poele RH, Eve PD, Valenti MR, de Haven Brandon AK, Martins V, Zetterlund A, Heaton SP, et al: AT13148 is a novel, oral multi-AGC kinase inhibitor with potent pharmacodynamic and antitumor activity. Clin Cancer Res 18: 3912-3923, 2012.

73. Lin X, Murray JM, Rico AC, Wang MX, Chu DT, Zhou Y, Del Rosario M, Kaufman S, Ma S, Fang E, et al: Discovery of 2-pyrimidyl-5-amidothiophenes as potent inhibitors for AKT: Synthesis and SAR studies. Bioorg Med Chem Lett 16 : 4163-4168, 2006.

74. Dumble M, Crouthamel MC, Zhang SY, Schaber M, Levy D Robell K, Liu Q, Figueroa DJ, Minthorn EA, Seefeld MA, et al: Discovery of novel AKT inhibitors with enhanced anti-tumor effects in combination with the MEK inhibitor. PLoS One 9: e100880, 2014

75. Chang S, Zhang Z, Zhuang X, Luo J, Cao X, Li H, Tu Z, Lu X, Ren $X$ and Ding K: New thiazole carboxamides as potent inhibitors of Akt kinases. Bioorg Med Chem Lett 22: 1208-1212, 2012.

76. Deng R, Yang F, Chang SH, Tang J, Qin J, Feng GK, Ding K and Zhu XF: DC120, a novel and potent inhibitor of AKT kinase, induces tumor cell apoptosis and suppresses tumor growth. Mol Pharmacol 82: 189-198, 2012.

77. Spencer A, Yoon SS, Harrison SJ, Morris SR, Smith DA, Brigandi RA, Gauvin J, Kumar R, Opalinska JB and Chen C: The novel AKT inhibitor afuresertib shows favorable safety, pharmacokinetics, and clinical activity in multiple myeloma. Blood 124: 2190-2195, 2014.

78. Faiman B and Richards T: Innovative agents in multiple myeloma. J Adv Pract Oncol 5: 193-202, 2014.

79. Wu WI, Voegtli WC, Sturgis HL, Dizon FP, Vigers GPA and Brandhuber BJ: Crystal structure of human AKT1 with an allosteric inhibitor reveals a new mode of kinase inhibition. PLoS One 5: e12913, 2010.

80. Lu S, Li S and Zhang J: Harnessing allostery: A novel approach to drug discovery. Med Res Rev 34: 1242-1285, 2014.

81. Lindsley CW, Zhao Z, Leister WH, Robinson RG, Barnett SF, Defeo-Jones D, Jones RE, Hartman GD, Huff JR, Huber HE, et al: Allosteric Akt (PKB) inhibitors: Discovery and SAR of isozyme selective inhibitors. Bioorg Med Chem Lett 15: 761-764, 2005 .
82. Bilodeau MT, Balitza AE, Hoffman JM, Manley PJ, Barnett SF, Defeo-Jones D, Haskell K, Jones RE, Leander K, Robinson RG, et al: Allosteric inhibitors of Akt1 and Akt2: A naphthyridinone with efficacy in an A2780 tumor xenograft model. Bioorg Med Chem Lett 18: 3178-3182, 2008.

83.Li Y, Liang J, Siu T, Hu E, Rossi MA, Barnett SF, Defeo-Jones D, Jones RE, Robinson RG, Leander K, et al: Allosteric inhibitors of Akt1 and Akt2: Discovery of [1,2,4]triazolo[3,4-f][1,6]naphthyridines with potent and balanced activity. Bioorg Med Chem Lett 19: 834-836, 2009.

84. Hirai H, Sootome H, Nakatsuru Y, Miyama K, Taguchi S, Tsujioka K, Ueno Y, Hatch H, Majumder PK, Pan BS, et al: MK-2206, an allosteric Akt inhibitor, enhances antitumor efficacy by standard chemotherapeutic agents or molecular targeted drugs in vitro and in vivo. Mol Cancer Ther 9: 1956-1967, 2010.

85. Fang Z, Simard JR, Plenker D, Nguyen HD, Phan T, Wolle P, Baumeister S and Rauh D: Discovery of inter-domain stabilizers-a novel assay system for allosteric akt inhibitors. ACS Chem Biol 10: 279-288, 2015.

86.Jiao P, Zhou YS, Yang JX, Zhao YL, Liu QQ, Yuan C and Wang FZ: MK-2206 induces cell cycle arrest and apoptosis in HepG2 cells and sensitizes TRAIL-mediated cell death. Mol Cell Biochem 382: 217-224, 2013.

87. Molife LR, Yan L, Vitfell-Rasmussen J, Zernhelt AM, Sullivan DM, Cassier PA, Chen E, Biondo A, Tetteh E, Siu LL, et al: Phase 1 trial of the oral AKT inhibitor MK-2206 plus carboplatin/paclitaxel, docetaxel, or erlotinib in patients with advanced solid tumors. J Hematol Oncol 7: 1, 2014.

88. Kümler I, Tuxen MK and Nielsen DL: A systematic review of dual targeting in HER2-positive breast cancer. Cancer Treat Rev 40: 259-270, 2014.

89. Konopleva MY, Walter RB, Faderl SH, Jabbour EJ, Zeng Z, Borthakur G, Huang X, Kadia TM, Ruvolo PP, Feliu JB, et al: Preclinical and early clinical evaluation of the oral AKT inhibitor, MK-2206, for the treatment of acute myelogenous leukemia. Clin Cancer Res 20: 2226-2235, 2014.

90.Do K, Speranza G, Bishop R, Khin S, Rubinstein L, Kinders RJ, Datiles M, Eugeni M, Lam MH, Doyle LA, et al: Biomarker-driven phase 2 study of MK-2206 and selumetinib (AZD6244, ARRY-142886) in patients with colorectal cancer. Invest New Drugs 33: 720-728, 2015.

91. Meuillet EJ: Novel inhibitors of AKT: Assessment of a different approach targeting the pleckstrin homology domain. Curr Med Chem 18: 2727-2742, 2011.

92. Gills JJ and Dennis PA: Perifosine: Update on a novel Akt inhibitor. Curr Oncol Rep 11: 102-110, 2009.

93.van Blitterswijk WJ and Verheij M: Anticancer mechanisms and clinical application of alkylphospholipids. Biochim Biophys Acta 1831: 663-674, 2013.

94. van der Luit AH, Vink SR, Klarenbeek JB, Perrissoud D, Solary E, Verheij M and van Blitterswijk WJ: A new class of anticancer alkylphospholipids uses lipid rafts as membrane gateways to induce apoptosis in lymphoma cells. Mol Cancer Ther 6: 2337-2345, 2007.

95.Reis-Sobreiro M, Roué G, Moros A, Gajate C, de la Iglesia-Vicente J, Colomer D and Mollinedo F: Lipid raft-mediated Akt signaling as a therapeutic target in mantle cell lymphoma. Blood Cancer J 3: e118, 2013.

96. Pachioni JdeA, Magalhães JG, Lima EJC, Bueno LdeM, Barbosa JF, de Sá MM and Rangel-Yagui CO: Alkylphospholipids - a promising class of chemotherapeutic agents with a broad pharmacological spectrum. J Pharm Pharm Sci 16: 742-759, 2013.

97.Giantonio BJ, Derry C, McAleer C, McPhillips JJ and O'Dwyer PJ: Phase I and pharmacokinetic study of the cytotoxic ether lipid ilmofosine administered by weekly two-hour infusion in patients with advanced solid tumors. Clin Cancer Res 10: 1282-1288, 2004

98. Verweij J, Krzemieniecki K, Kok T, Poveda A, van Pottelsberghe $\mathrm{C}$, van Glabbeke $\mathrm{M}$ and Mouridsen H: Phase II study of miltefosine (hexadecylphosphocholine) in advanced soft tissue sarcomas of the adult - an EORTC Soft Tissue and Bone Sarcoma Group Study. Eur J Cancer 29A: 208-209, 1993.

99. Becher R, Kloke K, Füger A, Bremer K, Drozd A, Kleeberg UR, Fritze D, Rieche K and Sindermann H: Phase II Trial of Orally Administered Miltefosine in Advanced Colorectal Cancer. Onkologie 16: 11-15, 1993.

100. Clive S, Gardiner J and Leonard RCF: Miltefosine as a topical treatment for cutaneous metastases in breast carcinoma. Cancer Chemother Pharmacol Suppl 44, 2000. 
101.Dorlo TPC, Balasegaram M, Beijnen JH and de Vries PJ: Miltefosine: A review of its pharmacology and therapeutic efficacy in the treatment of leishmaniasis. J Antimicrob Chemother 67: 2576-2597, 2012.

102. Orlowski RZ: Novel agents for multiple myeloma to overcome resistance in phase III clinical trials. Semin Oncol 40: 634-651, 2013.

103. Henke G, Lindner LH, Vogeser M, Eibl HJ, Wörner J, Müller AC, Bamberg M, Wachholz K, Belka $\mathrm{C}$ and Jendrossek V: Pharmacokinetics and biodistribution of Erufosine in nude mice - implications for combination with radiotherapy. Radiat Oncol 4: 46, 2009.

104. Rübel A, Handrick R, Lindner LH, Steiger M, Eibl H, Budach W, Belka C and Jendrossek V: The membrane targeted apoptosis modulators erucylphosphocholine and erucylphosphohomocholine increase the radiation response of human glioblastoma cell lines in vitro. Radiat Oncol 1: 6, 2006.

105. Kaleağası ğlu F and Berger MR: Differential effects of erufosine on proliferation, wound healing and apoptosis in colorectal cancer cell lines. Oncol Rep 31: 1407-1416, 2014.

106. Rudner J, Ruiner CE, Handrick R, Eibl HJ, Belka C and Jendrossek V: The Akt-inhibitor Erufosine induces apoptotic cell death in prostate cancer cells and increases the short term effects of ionizing radiation. Radiat Oncol 5: 108, 2010.

107. Chinni SR and Sarkar FH: Akt inactivation is a key event in indole-3-carbinol-induced apoptosis in PC-3 cells. Clin Cancer Res 8: 1228-1236, 2002.

108. Aggarwal BB and Ichikawa $\mathrm{H}$ : Molecular targets and anticancer potential of indole-3-carbinol and its derivatives. Cell Cycle 4: 1201-1215, 2005.

109. Kim DJ, Reddy K, Kim MO, Li Y, Nadas J, Cho YY, Kim JE, Shim JH, Song NR, Carper A, et al: (3-Chloroacetyl)-indole, a novel allosteric AKT inhibitor, suppresses colon cancer growth in vitro and in vivo. Cancer Prev Res (Phila) 4: 1842-1851, 2011.

110. Chao WR, Yean D, Amin K, Green C and Jong L: Computer-aided rational drug design: A novel agent (SR13668) designed to mimic the unique anticancer mechanisms of dietary indole-3-carbinol to block Akt signaling. J Med Chem 50: 3412-3415, 2007.

111. Kapetanovic IM, Muzzio M, Hu S-C, Crowell JA, Rajewski RA, Haslam JL, Jong L and McCormick DL: Pharmacokinetics and enhanced bioavailability of candidate cancer preventative agent, SR13668 in dogs and monkeys. Cancer Chemother Pharmacol 65: 1109-1116, 2010.

112. Reid JM, Walden CA, Qin R, Ziegler KL, Haslam JL, Rajewski RA, Warndahl R, Fitting CL, Boring D, Szabo E, et al Cancer Prevention Network: Phase 0 clinical chemoprevention trial of the Akt inhibitor SR13668. Cancer Prev Res (Phila) 4: 347-353, 2011.

113. Weng JR, Tsai CH, Omar HA, Sargeant AM, Wang D, Kulp SK, Shapiro CL and Chen CS: OSU-A9, a potent indole-3-carbinol derivative, suppresses breast tumor growth by targeting the Akt-NF-kappaB pathway and stress response signaling. Carcinogenesis 30: 1702-1709, 2009.

114. Mahadevan D, Powis G, Mash EA, George B, Gokhale VM, Zhang S, Shakalya K, Du-Cuny L, Berggren M, Ali MA, et al: Discovery of a novel class of AKT pleckstrin homology domain inhibitors. Mol Cancer Ther 7: 2621-2632, 2008.

115. Moses SA, Ali MA, Zuohe S, Du-Cuny L, Zhou LL, Lemos R, Ihle N, Skillman AG, Zhang S, Mash EA, et al: In vitro and in vivo activity of novel small-molecule inhibitors targeting the pleckstrin homology domain of protein kinase B/AKT. Cancer Res 69: 5073-5081, 2009.

116. Meuillet EJ, Zuohe S, Lemos R, Ihle N, Kingston J, Watkins R, Moses SA, Zhang S, Du-Cuny L, Herbst R: Molecular pharmacology and antitumor activity of PHT-427, a novel Akt/ phosphatidylinositide-dependent protein kinase 1 pleckstrin homology domain inhibitor. Mol Cancer Ther 9: 706-717, 2010.

117. Miao B, Skidan I, Yang J, Lugovskoy A, Reibarkh M, Long K, Brazell T, Durugkar KA, Maki J, Ramana CV, et al: Small molecule inhibition of phosphatidylinositol-3,4,5-triphosphate (PIP3) binding to pleckstrin homology domains. Proc Natl Acad Sci USA 107: 20126-20131, 2010.

118. Kommagalla Y, Cornea S, Riehle R, Torchilin V, Degterev A and Ramana CV: Optimization of the anti-cancer activity of phosphatidylinositol-3 kinase pathway inhibitor PITENIN-1: Switching a thiourea with 1,2,3-triazole. MedChemComm 5: 1359-1363, 2014.

119. Nitulescu GM, Draghici C, Olaru OT, Matei L, Ioana A, Dragu LD and Bleotu C: Synthesis and apoptotic activity of new pyrazole derivatives in cancer cell lines. Bioorg Med Chem 23: 5799-5808, 2015.
120. Yang L, Dan HC, Sun M, Liu Q, Sun XM, Feldman RI, Hamilton AD, Polokoff M, Nicosia SV, Herlyn M, et al: Akt/protein kinase B signaling inhibitor-2, a selective small molecule inhibitor of Akt signaling with antitumor activity in cancer cells overexpressing Akt. Cancer Res 64: 4394-4399, 2004

121. Sampath D, Malik A, Plunkett W, Nowak B, Williams B, Burton M, Verstovsek S, Faderl S, Garcia-Manero G, List AF, et al: Phase I clinical, pharmacokinetic, and pharmacodynamic study of the Akt-inhibitor triciribine phosphate monohydrate in patients with advanced hematologic malignancies. Leuk Res 37: 1461-1467, 2013.

122.Berndt N, Yang H, Trinczek B, Betzi S, Zhang Z, Wu B, Lawrence NJ, Pellecchia M, Schönbrunn E, Cheng JQ, et al: The Akt activation inhibitor TCN-P inhibits Akt phosphorylation by binding to the $\mathrm{PH}$ domain of Akt and blocking its recruitment to the plasma membrane. Cell Death Differ 17: 1795-1804, 2010.

123. Evangelisti C, Ricci F, Tazzari P, Chiarini F, Battistelli M, Falcieri E, Ognibene A, Pagliaro P, Cocco L, McCubrey JA, et al: Preclinical testing of the Akt inhibitor triciribine in T-cell acute lymphoblastic leukemia. J Cell Physiol 226: 822-831, 2011.

124. Dieterle A, Orth R, Daubrawa M, Grotemeier A, Alers S, Ullrich S, Lammers R, Wesselborg S and Stork B: The Akt inhibitor triciribine sensitizes prostate carcinoma cells to TRAIL-induced apoptosis. Int J Cancer 125: 932-941, 2009.

125.Kim R, Yamauchi T, Husain K, Sebti S and Malafa M: Triciribine Phosphate Monohydrate, an AKT Inhibitor, Enhances Gemcitabine Activity in Pancreatic Cancer Cells. Anticancer Res 35: 4599-4604, 2015.

126. Kim D, Sun M, He L, Zhou QH, Chen J, Sun XM, Bepler G, Sebti SM and Cheng JQ: A small molecule inhibits Akt through direct binding to Akt and preventing Akt membrane translocation. J Biol Chem 285: 8383-8394, 2010.

127. Li B, Ren H, Yue P, Chen M, Khuri FR and Sun SY: The novel Akt inhibitor API-1 induces c-FLIP degradation and synergizes with TRAIL to augment apoptosis independent of Akt inhibition. Cancer Prev Res (Phila) 5: 612-620, 2012.

128. Ashwell MA, Lapierre J-M, Brassard C, Bresciano K, Bull C, Cornell-Kennon S, Eathiraj S, France DS, Hall T, Hill J, et al: Discovery and optimization of a series of 3-(3-phenyl$3 \mathrm{H}$-imidazo[4,5-b]pyridin-2-yl)pyridin-2-amines: Orally bioavailable, selective, and potent ATP-independent Akt inhibitors. J Med Chem 55: 5291-5310, 2012.

129. Chan TCK, Lapierre JM, Ashwell MA, France DS, Chen CR, Cornell-Kennon S, Bull C, Eathiraj S, Palma R, Liu Y, et al: Abstract A230: Discovery and characterization of ARQ 092, an ATP-independent, potent and selective inhibitor of AKT kinases. Mol Cancer Ther 10 (Suppl 1): A230-A230, 2011.

130. Yu Y, Savage RE, Eathiraj S, Meade J, Wick MJ, Hall T, Abbadessa G and Schwartz B: Targeting AKT1-E17K and the PI3K/AKT pathway with an allosteric AKT inhibitor, ARQ 092. PLoS One 10: e0140479, 2015.

131. Politz O, Scholz A, Haegebarth A, Liu N, Baerfacker L, Ince S, Neuhaus R, Boemer U, Michels $M$ and Mumberg D: Abstract 3685: BAY 1125976, is a selective allosteric AKT1/2 inhibitor with high efficacy in AKT1-mutated cancers. Cancer Res 74 (Suppl 19): 3685, 2014.

132. Yilmaz OG, Olmez EO and Ulgen KO: Targeting the Akt1 allosteric site to identify novel scaffolds through virtual screening. Comput Biol Chem 48: 1-13, 2014.

133. Estrada AC, Syrovets T, Pitterle K, Lunov O, Büchele B, Schimana-Pfeifer J, Schmidt T, Morad SA and Simmet T: Tirucallic acids are novel pleckstrin homology domain-dependent Akt inhibitors inducing apoptosis in prostate cancer cells. Mol Pharmacol 77: 378-387, 2010.

134. Morrow JK, Du-Cuny L, Chen L, Meuillet EJ, Mash EA, Powis $G$ and Zhang S: Recent development of anticancer therapeutics targeting Akt. Recent Patents Anticancer Drug Discov 6: 146-159, 2011.

135. Toral-Barza L, Zhang WG, Huang X, McDonald LA, Salaski EJ, Barbieri LR, Ding WD, Krishnamurthy G, Hu YB, Lucas J, et al: Discovery of lactoquinomycin and related pyranonaphthoquinones as potent and allosteric inhibitors of AKT/PKB: Mechanistic involvement of AKT catalytic activation loop cysteines. Mol Cancer Ther 6: 3028-3038, 2007.

136. Salaski EJ, Krishnamurthy G, Ding WD, Yu K, Insaf SS, Eid C, Shim J, Levin JI, Tabei K, Toral-Barza L, et al: Pyranonaphthoquinone lactones: A new class of AKT selective kinase inhibitors alkylate a regulatory loop cysteine. J Med Chem 52: 2181-2184, 2009. 
137. Nguyen T, Coover RA, Verghese J, Moran RG and Ellis KC: Phenylalanine-Based Inactivator of AKT Kinase: Design, synthesis, and biological evaluation. ACS Med Chem Lett 5: 462-467, 2014.

138. Shearn CT, Reigan P and Petersen DR: Inhibition of hydrogen peroxide signaling by 4-hydroxynonenal due to differential regulation of Akt1 and Akt 2 contributes to decreases in cell survival and proliferation in hepatocellular carcinoma cells. Free Radic Biol Med 53: 1-11, 2012.

139. Weisner J, Gontla R, van der Westhuizen L, Oeck S, Ketzer J, Janning P, Richters A, Mühlenberg T, Fang Z, Taher A, et al: Covalent-allosteric kinase inhibitors. Angew Chem Int Ed Engl 54: 10313-10316, 2015

140. She QB, Chandarlapaty S, Ye Q, Lobo J, Haskell KM, Leander KR, DeFeo-Jones D, Huber HE and Rosen N: Breast tumor cells with PI3K mutation or HER2 amplification are selectively addicted to Akt signaling. PLoS One 3: e3065, 2008.

141. Sangai T, Akcakanat A, Chen H, Tarco E, Wu Y, Do KA, Miller TW, Arteaga CL, Mills GB, Gonzalez-Angulo AM and Meric-Bernstam F: Biomarkers of response to Akt inhibitor MK-2206 in breast cancer. Clin Cancer Res 18: 5816-5828, 2012.

142. Davies BR, Greenwood H, Dudley P, Crafter C, Yu DH, Zhang J, Li J, Gao B, Ji Q, Maynard J, et al: Preclinical pharmacology of AZD5363, an inhibitor of AKT: pharmacodynamics, antitumor activity, and correlation of monotherapy activity with genetic background. Mol Cancer Ther 11: 873-887, 2012.
143. Yap TA, Yan L, Patnaik A, Fearen I, Olmos D, Papadopoulos K, Baird RD, Delgado L, Taylor A, Lupinacci L, et al: First-in-man clinical trial of the oral pan-AKT inhibitor MK-2206 in patients with advanced solid tumors. J Clin Oncol 29: 4688-4695, 2011.

144. Saura C, Jones S, Mateo J, Hollebecque A, Cleary JM, Perez DR, Zhu J, Musib LC, Patel PH, Cervantes-Ruiperez A, et al: A phase Ib study of the Akt inhibitor GDC-0068 with docetaxel (D) or mFOLFOX-6 (F) in patients (pts) with advanced solid tumors. J Clin Oncol 30 (Suppl; abstr 3021), 2012.

145. Yan Y, Wagle M, Punnoose E, Musib L, Budha N, Nannini M, Lin K, Liederer BM, Murli S, Ramakrishnan V, et al: A first-inhuman trial of GDC-0068: A novel, oral, ATP-competitive Akt inhibitor, demonstrates robust suppression of the Akt pathway in surrogate and tumor tissues. Mol Cancer Ther 10: abstr B154, 2011.

146. Banerij U, Ranson M, Schellens J, Schellens JH, Esaki T, Dean EJ and Zivi A: Results of two phase I multicenter trials of AZD5363, an inhibitor of AKT1, 2 and 3: Biomarker and early clinical evaluation in Western and Japanese patients with advanced solid tumors. Cancer Res 73: abstr LB-66, 2013.

147.Dienstmann R, Rodon J, Serra V and Tabernero J: Picking the point of inhibition: A comparative review of PI3K/AKT/mTOR pathway inhibitors. Mol Cancer Ther 13: 1021-1031, 2014. 